University of Rhode Island

DigitalCommons@URI

Open Access Master's Theses

2007

\title{
The Effects of Fire and Shrub Cutting on Rare and Endangered Plants in the Ninigret National Wildlife Refuge
}

Amanda Clifton

University of Rhode Island

Follow this and additional works at: https://digitalcommons.uri.edu/theses

\section{Recommended Citation}

Clifton, Amanda, "The Effects of Fire and Shrub Cutting on Rare and Endangered Plants in the Ninigret National Wildlife Refuge" (2007). Open Access Master's Theses. Paper 1437.

https://digitalcommons.uri.edu/theses/1437

This Thesis is brought to you for free and open access by DigitalCommons@URI. It has been accepted for inclusion in Open Access Master's Theses by an authorized administrator of DigitalCommons@URI. For more information, please contact digitalcommons-group@uri.edu. 
THE EFFECTS OF FIRE AND SHRUB CUTTING ON RARE AND ENDANGERED PLANTS IN THE NINIGRET NATIONAL WILDLIFE REFUGE

BY

AMANDA CLIFTON

\begin{abstract}
A THESIS SUBMITTED IN PARTIAL FULFILLMENT OF THE
REQUIREMENTS FOR THE DEGREE OF

MASTERS OF SCIENCE

IN

BIOLOGICAL SCIENCES
\end{abstract}

UNIVERSITY OF RHODE ISLAND

2007 


\section{MASTERS OF SCIENCE THESIS}

OF

AMANDA CLIFTON

\section{APPROVED:}

Thesis Committee:

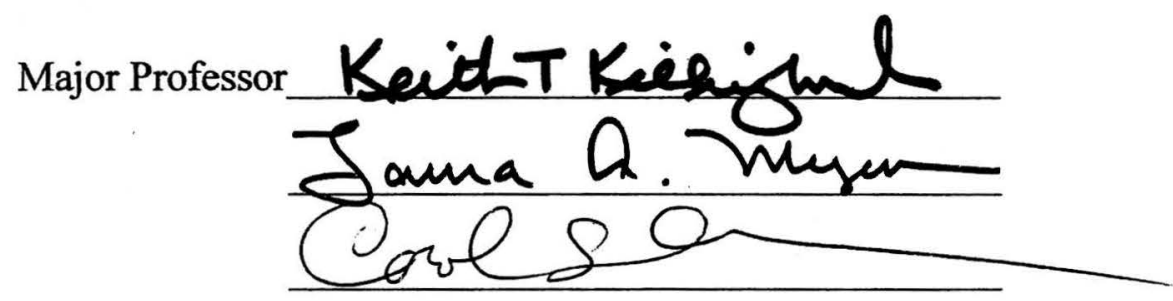

DEAN OF THE GRADUATE SCHOOL

\section{UNIVERSITY OF RHODE ISLAND}

2007 


\begin{abstract}
The decline in rare plant populations and the decrease in size of their native ranges have led to escalating losses of biodiversity. A combination of shrub cutting and fire was applied to an endangered species "hot spot" in southern Rhode Island, USA to determine the effects of these treatments on a group of eight rare herbaceous plant species exposed to ever-increasing encroachment by tall shrubs. Shrub cutting and fire were also applied to a shrub-dominated area adjacent to the hot spot to determine if it was possible to promote establishment and growth of the rare plants in areas in which they were not found in abundance. My analyses focused on the three rare species that were found in greatest abundance within the rare plant area; Aletris farinosa, Platanthera ciliaris, and Polygala cruciata. Fire appeared to have a positive effect on the reproductive output of the endangered orchid Platanthera ciliaris; the mean density of inflorescences doubled from 0.70 inflorescences $/ \mathrm{m}^{2}$ in 2005 to 1.41 inflorescences $/ \mathrm{m}^{2}$ in 2006 in plots that were burned. However, this difference was not statistically significant. Significant differences in vegetation characteristics were observed between plots in which rare plants were present and plots in which rare plants were absent. Platanthera and Aletris had negative relationships with woody plant cover, and positive relationships with herbaceous plant cover. The density of Aletris was significantly correlated with the density of Drosera $\mathrm{sp} .(\mathrm{r}=0.73, \mathrm{P}<0.001)$, a species indicative of disturbed, nutrient poor environments. Fire had no effect on the cover of woody plants within the rare plant area, however, fire did have an effect on the cover and height of woody plants in adjacent experimental sectors. In 2006, all combinations of shrub cutting and fire decreased the cover and height of woody plants
\end{abstract}


in these sectors. No rare plants were found in the sector plots adjacent to the rare plant area, but the cut treatment applied to one of these sectors caused the rapid proliferation of the invasive woody vine Celastrus orbiculatus. The density of Celastrus was an order of magnitude higher in the cut sector than in the control. In an adjacent sector that was both cut and burned, the native shrub Rhus copallinum produced a similar rapid response to the treatment. Continued management must now focus on limiting the potential harmful impacts of Celastrus while promoting growth and establishment of the rare plants at the site. 


\section{Acknowledgments}

I thank Peter Keller for data collection in 2002-2004. I also thank Chelsea Dion for her help with field sampling and site preparation in the summer of 2005 , and Rick Enser for his assistance with plant identification in the summer of 2006 . I thank James Heltshe for his help and advice on statistical analyses. Thanks to Suzanne Paton, Charlie Vandermeor, and staff from the U.S. Fish and Wildlife Service for providing the resources and support that made the burning and cutting manipulations for this study possible. I also thank Eric Morales for his assistance in excavating the scarified plots. Laura Meyerson, Carol Thornber, and Larry Englander provided helpful feedback and advice regarding this study. Finally, I thank Keith Killingbeck for his guidance and comments, which greatly improved this manuscript. 


\section{Table of Contents}

Abstract

Acknowledgements iv

List of Tables $\quad$ vi

List of Figures vii

Introduction 1

Site Description $\quad 6$

$\begin{array}{lr}\text { Methods } & 9\end{array}$

$\begin{array}{ll}\text { Results } & 15\end{array}$

$\begin{array}{ll}\text { Discussion } & 23\end{array}$

Appendix A $\quad 55$

$\begin{array}{lr}\text { Appendix B } & 56\end{array}$

$\begin{array}{lr}\text { Appendix C } & 58\end{array}$

$\begin{array}{ll}\text { Appendix D } & 60\end{array}$

$\begin{array}{ll}\text { Bibliography } & 63\end{array}$ 


\section{List of Tables}

Table 1: Estimated population sizes of rare plants

Table 2: Maximum temperatures reached in burned plots

Table 3: Density of stems, density of inflorescences and percent cover of Aletris,

Platanthera, and Polygala

Table 4: Density and/or percent cover of all other habitat variables sampled

Table 5: Density of stems, density of inflorescences and percent cover of Aletris,

Platanthera, and Polygala in unburned plots

Table 6: Density and/or percent cover of all other habitat variables sampled in

unburned plots

Table 7: Regression coefficients 


\section{List of Figures}

$\begin{array}{ll}\text { Figure 1: Site map } & 41\end{array}$

Figure 2: Site map with plot numbers $\quad 42$

Figure 3: Images of Aletris, Platanthera, and Polygala 43

Figure 4: Density of stems of Aletris, Platanthera, and Polygala 44

Figure 5: Density of inflorescences of Aletris, Platanthera, and Polygala 45

Figure 6: Cover of Aletris, Platanthera, and Polygala 46

Figure 7: Mean change in Aletris, Platanthera and Polygala in burned and $\quad 47$

unburned plots

Figure 8: Cover of Drosera, lichens, unvegetated soil, and moss 48

Figure 9: Mean change in Drosera, lichens, unvegetated soil, moss, 49 herbaceous and woody plants

Figure 10: Cover and height of herbaceous and woody vegetation $\quad 50$

Figure 11: Cover of Drosera, lichens, unvegetated soil, and moss in plots 51 that were occupied and unoccupied by rare plants

Figure 12: Cover and height of herbaceous and woody vegetation in plots 52 that were occupied and unoccupied by rare plants

Figure 13: Density of Celastrus and Rhus in experimental sectors 53

Figure 14: Cover and height of herbaceous and woody vegetation in 54 experimental sectors 


\section{Introduction}

The significant loss of rare plant populations and the decrease in size of their historical ranges is a problem both regionally in New England (Farnsworth and Ogurcak 2006) and throughout the world (Kirkpatrick and Gilffeder 1995, Norton and De Lange 2003, Wotavova et al. 2004). There are, however, extant sites that still support relatively large numbers of rare plant populations, thus contributing to locally high levels of biodiversity (Farnsworth and Ogurcak 2006). These areas are often called "hot spots" of biodiversity and are critical to conservation efforts because preservation and management of relatively small areas of land can protect disproportionately large numbers of rare species (Dobson et al. 1997).

One such endangered species "hot spot" exists within the Ninigret National Wildlife Refuge (NNWR) in Charlestown, Rhode Island (Killingbeck et al. 1998). An area just $2,300 \mathrm{~m}^{2}$ in size supports an assemblage of at least eight species of plants considered to be rare or endangered in the state of Rhode Island and found at few other localities in the state (Enser 2002). The "endangered species hot spot" at Ninigret contains more individuals of the state-endangered yellow-fringed orchid, Platanthera ciliaris, than all of the rest of New England combined (Killingbeck et al. 1998). When the site was first discovered in 1993, it was clear that the relatively small area provided habitat for a variety of biologically important plant species.

When earlier field studies were initiated at the site, it was apparent that, while rare plant density was extremely high within the $2,300 \mathrm{~m}^{2}$ core of the hot spot, relatively few rare plants existed beyond the boundaries of this area. The curious presence of an abrupt, definitive boundary coupled with an equally abrupt difference 
in soil organic matter suggested that anthropogenic disturbance played a key role in the development of vegetation at this site (Killingbeck et al. 1998). However, the limited disturbance history of the site offers limited clues to deduce the profound landscape changes that have occurred in the past 100 years. Additionally, there is even a high degree of uncertainty regarding the species composition and structure of all coastal New England vegetation in presettlement times (Day 1953, Foster and Motzkin 2003, Marks 1983).

While disturbance can lead to the outright destruction and elimination of communities, it can also promote variation in the landscape and, in turn, provide conditions necessary to enhance species richness (Kirkpatrick and Gilfedder 1995). Cultural practices such as mowing, plowing, and burning have perpetuated grasslands and shrublands for hundreds of years by preventing their progression to forested systems (Foster and Motzkin 2003). However, changes in land use have led to the cessation of certain historical disturbance regimes and, in turn, the preservation of habitats that support many rare and unique species of plants (Hall et al. 2002, Latham 2003). It is necessary to reconcile the historical and environmental influences that have impacted the landscape in order to actively conserve these important habitats (Foster 2002, Foster and Motzkin 2003, Neill et al. 2007).

Rare plants are frequently found within anthropogenically-disturbed landscapes (Latham 2003, Zaremba 2004), and much work has been done to explore the relationships between rare plants and disturbance history (Baskin et al. 1997, Clarke and Patterson 2006, Vickery 2001). For many rare North Atlantic coastal plant species, disturbance is necessary to provide the environmental conditions that 
favor their existence at a particular site (Clarke and Patterson 2006, Motzkin and Foster 2002). Fire functions as one such critical disturbance in early successional communities and has been shown to promote growth and flowering in some herbaceous plants (Jacobson et al. 1991). Many studies have shown that flowering in orchids and other geophytes is enhanced by fire (Lamont and Runciman 1993, Whelan 1995), and consequently, larger populations are observed after burning (Lunt 1997, Norton and de Lange 2003, Stuckey 1967). Fire can also have indirect effects, one of which is the removal of competing vegetation (Jacobson et al. 1991), which increases both light availability and openings for seedling establishment (Gankin and Major 1964).

Tree and shrub clearing has also been used as a method to promote or restore biodiversity to a system facing increased encroachment of vegetation capable of outcompeting target species (Barbaro et al. 2001). Many rare, herbaceous plants depend on open, short vegetation with patches of bare ground for establishment (Dolman and Southerland 1992). Habitat for low-growing species is often maintained by disturbance or grazing, however, restoration efforts, such as shrub cutting, can simulate such processes (Zobel et al. 1996). In the absence of alternative management, shrubs and trees are likely to dominate communities that were formerly composed of species of shorter stature (Bakker et al. 1996, Bullock and Pakeman 1997).

Previous studies at the Ninigret site offered evidence that shrub cutting and/or fire had a positive effect on at least four species of rare plants (Keller and Killingbeck 2004), yet additional experiments were needed to determine whether continued 
frequent, periodic fire would elicit a similar response. To understand how the practice of prescribed burning might change the population dynamics of the rare plants at the site, experimental manipulations including a combination of shrub cutting and fire were utilized at the Ninigret Endangered Species Area (NESA) to reduce light limitation due to shading.

An additional goal of the study was to determine whether areas beyond the margins of the rare plant "hot spot" could be manipulated to provide the conditions necessary for establishment and growth of the rare plants. The experimental design included clearing a shrub-dominated area adjacent to the "endangered species hot spot" with three combinations of shrub cutting and fire to determine how areas harboring few, if any, rare species would respond. The discovery of a number of stems of Platanthera ciliaris in 2004 in a mowed firebreak adjacent to the hot spot suggested that such manipulations could be instrumental in increasing the population sizes of at least some of the rare plant species beyond the core area.

The main objective of the study was to determine the efficacy of using shrub cutting and fire to enhance populations of rare plants that might otherwise face shadeinduced reductions, or extirpation. This study aimed to address the following specific questions: (1) what are the estimated population sizes for the rare plant species found within the NESA core?; (2) does the application of fire or shrub cutting change the density, percent cover, or number of inflorescences for the rare plants or associated vegetation within the NESA core?; (3) what habitat characteristics are most highly related to the distribution and abundance of the rare species at this site?; and (4) what are the effects of fire and shrub cutting on tall shrubs adjacent to the NESA core, and 
does burning, cutting, or scarification promote establishment of rare plants outside of the "hot spot"? 


\section{Site Description}

The study took place within the Ninigret National Wildlife Refuge, located in Charlestown, Rhode Island $\left(41^{\circ} 22^{\prime} \mathrm{N}, 71^{\circ} 40^{\prime} \mathrm{W}\right)$. The site is directly adjacent to Ninigret Pond, an inland brackish pond separated from Block Island Sound by a barrier beach. The complete study area within a perimeter firebreak ('site') includes the $2,300 \mathrm{~m}^{2}$ Ninigret endangered species area "hot spot" (to be referred to as "NESA core'), and the areas adjacent to the NESA core that were treated in 2005 (to be referred to as 'experimental sectors'). With the addition of the experimental treatment sectors in 2005 , the entire site encompasses over $7,300 \mathrm{~m}^{2}$ including the control sector $\left(1,600 \mathrm{~m}^{2}\right)$ the burn sector $\left(1,200 \mathrm{~m}^{2}\right)$, the cut sector $\left(1,220 \mathrm{~m}^{2}\right)$, and the cut and burn sector $\left(660 \mathrm{~m}^{2}\right)$.

The site is dominated by shrubs, grasses, and many low-growing herbaceous plants. Dominant shrub species include Myrica pennsylvanica L. (bayberry), Clethra alnifolia L. (sweet pepperbush), Amelanchier canadensis (L.) Medik. (shadbush), and Vaccinium corymbosum L. (highbush blueberry). Grass species identified at the site include Andropogon gerardii Nash. (big blue stem), and Phalaris arundinacea L. (reed canary grass), while plants such as Vaccinium macrocarpon Ait. (cranberry), Drosera sp. L. (sundew), as well as a variety of lichen and moss species are all part of this unique community.

The NESA core supports multiple species of rare plants and has been sampled repeatedly since 1996. The eight known species of rare plants are Aletris farinosa L. (colic root; Rhode Island state threatened), Platanthera ciliaris (L.) Lindl. (yellowfringed orchid; Rhode Island state endangered), Polygala cruciata L. (Marsh 
milkwort; Rhode Island state threatened), Spiranthes tuberosa Raf. (little ladies'tresses, Rhode Island state endangered), Scleria pauciflora Muhl. (Carolina whipgrass; Rhode Island state threatened), Scleria triglomerata Michx. (whipgrass; Rhode Island state threatened), Sorghastrum nutans (L.) Nash (Indian grass; Rhode Island state concern), and Aristida longespica Poiret. (slimspike three-awn; Rhode Island state concern) (Enser 2002). Additionally, Platanthera ciliaris is considered to be regionally rare in New England (Division 2, State Endangered 1, Brumback and Mehrhoff 1996).

Aletris farinosa is one of just five species in the genus Aletris that occurs in North America (Sullivan 1973). Aletris, part of the family Liliaceae, is a geophyte with fleshy, underground tissues that serve reproductive and storage functions (Rutters et al. 1993). Like Aletris, Platanthera is a geophyte and part of the family Orchidaceae. Polygala, part of the family Polygalaceae, differs as it is an annual plant. The population of Aletris within the Ninigret National Wildlife Refuge is one of eight extant populations in the state of Rhode Island (Enser 2002). Including the Ninigret site, Platanthera and Polygala are documented in just two and three sites, respectively, in Rhode Island.

The Ninigret refuge is the former site of the United States Naval Auxiliary Air Station at Charlestown. Owned and operated by the U.S. Navy from 1943-1973, its primary use was in training Navy pilots for night flights. Due to their close proximity to open water, the runways at this site served to simulate aircraft carrier landing decks. During this time, considerable alterations took place in what is now refuge property, as evidence from pre- and post-base aerial photographs suggests. 


\begin{abstract}
Although no runways or buildings covered the rare plant site, observations of debris and remnants of equipment suggest that some type of disturbance took place. Aerial photos indicate that soil removal may have occurred during the U.S. Navy's ownership of the land. Soil samples taken within the rare plant area support this theory (Killingbeck et al. 1998).
\end{abstract}




\section{Methods}

Data previously obtained at this site (in 1996, 2002, 2003, and 2004; Keller and Killingbeck 2004) were collected from $610.5-\mathrm{m}^{2}$ permanent plots distributed throughout the NESA core along 13 transects (Killingbeck et al 1998). Transects were established perpendicular to a northeast/southwest line that bisected the NESA core, and were positioned in randomized locations within eight-meter intervals. Along each of the 13 transects, permanent sampling plots were established in randomized locations within four-meter intervals in the spring of 2005. Randomization within each four- and eight-meter segment was achieved by dividing each interval into one-meter units and then choosing by random draw the meter segment at which each plot would be located. All 87 original plots were sampled for the 2005-2006 study.

In 2005 , the area of dense woody shrubs beyond the NESA core was divided by five-meter wide firebreaks into four sectors and each sector was given a separate experimental treatment (Figure 1). This experimental design included plots that were cut and burned (Sector D), cut only (sector C), burned only (Sector B), and left untreated (control, Sector A, Figure 2). Treatments for the four sectors were assigned randomly. The original 13 transects were extended approximately $30-40 \mathrm{~m}$ to the northwest and ended at the perimeter firebreak that surrounds the site. Fifteen new plots were established in each of the four sectors along three expanded transect lines in each sector. The protocol for plot placement explained above was also used to expand the already existing transects and establish a total of 60 new $0.5-\mathrm{m}^{2}$ plots in the densely dominated shrub area beyond the original NESA core. 
Five plots on each transect line were distributed randomly at four-meter intervals. Due to constraints imposed by the shape of the cut and burn sector, plot placement deviated slightly from the above design (see Figure 1). If a four-meter interval fell within one meter of a tree, the four-meter interval was skipped and the plot was established within the next four-meter interval.

Geographic coordinates were taken directly over each permanent plot marker, firebreak boundaries and experimental sector boundaries with a Garmin handheld GPS unit, and were imported into ArcMap. All other geospatial data used for the site map were obtained from the Rhode Island Geographic Information System server (RIGIS 1989 and RIGIS 2005).

Fire and shrub-cutting treatments were formally approved by Suzanne Paton (Biologist, USFWS, Ninigret National Wildlife Refuge) and Rick Vollick (USFWS, Northeastern Regional 'Burn Boss') and were applied in spring 2005. Both the cutonly and the cut and burn sectors were mowed in late March 2005 using Brush Hog and Bat Wing mowers. Employees of the U.S. Fish and Wildlife service performed the cut treatments in these two sectors and also mowed three, five-meter wide firebreaks to separate the four new experimental sectors as well as the five-meter wide outer firebreak that surrounds the entire site. The NESA core, the burn sector, and the cut and burn sector were burned on 5 May 2005 by a team of fire management professionals from the U.S. Fish and Wildlife Service.

Temperature sensitive paints (Tempilaq, Tempil Division, Air Liquide America Corporation, South Plainfield, NJ) were deployed in each plot before the 2005 fire to measure the maximum temperature attained during the burn. A series of 
five paints with melting points of $200^{\circ} \mathrm{F}, 400^{\circ} \mathrm{F}, 600^{\circ} \mathrm{F}, 800^{\circ} \mathrm{F}$, and $1000^{\circ} \mathrm{F}$ were painted in thin strips on metal tags and were hung $10 \mathrm{~cm}$ above ground level prior to the burn. Tags were hung in all 61 core plots, in all 15 plots in the cut and burn sector, and all 15 plots in the burn sector. Tags were examined after the burn to determine the maximum temperature attained. Additional visual examination in the field immediately following the burn provided information on the extent of the burned area in each plot based on the percentage of surface area charred in each plot. Each burned plot in the core was assigned one of the following charring coverage classes: A (no charring), B (less than 5\% charring), C (5-20\% charring), D (20-40\% charring), E (40-60\% charring), F (60-80\% charring) G (80-99\% charring) and $\mathrm{H}$ (100\% charring).

Metal fire exclosures were deployed around 16 plots within the NESA core immediately prior to the burn. These rectangular sheet metal exclosures completely enclosed each $0.5-\mathrm{m}^{2}$ plot and included a $5-\mathrm{cm}$ buffer along all sides of each plot to protect the plants inside. Fire-exclosed plots were chosen in pairs based on treatments that were applied in 2003. Eight pairs of fire-exclosed plots were randomly chosen from all pairs of adjacent plots in which one of the plots had been experimentally cut in 2003 while the other in the tandem had not. These fireexcluded plots $(9,10,18,19,21,22,31,32,34,35,45,46,48,49,60,61)$, were also protected from a previous fire treatment in 2003 . Charring classes and Tempilaq tags were both used to confirm whether these plots were truly excluded from fire during the 2005 burn. 
Topsoil was removed from a group of $150.5-\mathrm{m}^{2}$ plots in the 2005 growing season to determine if the removal of topsoil plays a role in rare plant emergence or establishment. These scarified plots were created to mimic what appeared to be the removal of topsoil in the NESA core while the entire site was under U.S. Navy ownership over 50 years ago. The soil was removed to a depth of approximately 25 $\mathrm{cm}$ from 15 plots in the cut and burned sector. Each new scarified plot was offset from an established plot by one meter.

Collection of plant species data took place in August and September in both 2005 and 2006 within $0.5-\mathrm{m}^{2} \mathrm{PVC}$ quadrats that were placed over each aluminum or steel pipe that marked the northwest corner of each of the plots. The 87 plots original plots, as well as the 60 new plots and 15 scarified plots were sampled. Measurements for the eight rare plant species in all 162 plots included density (number of stems) and dominance (percent cover), numbers of stems with inflorescences, and maximum height of inflorescences. All plots were also assessed for the number and percent cover of the carnivorous sundew Drosera spp., percent cover of mosses, percent cover of lichens, percent cover and mean height of herbaceous and graminaceous species, percent cover and mean height of woody species, and percent cover of unvegetated soil. Collectively, these latter parameters were thought to be indicative of the recent disturbance history of this site (Brewer 1999, Eldridge et al 2000, Juniper et al 1989, Sedia and Ehrenfeld 2003). Sampling of the scarified plots took place in the summer of 2006 to determine if scarification on the periphery of the NESA core would promote the establishment of rare plant species. 
All plant nomenclature follows Gleason and Cronquist (1991) except for Platanthera ciliaris (Brumback and Mehrhoff 1996).

\section{Statistical Analyses}

Within the NESA core, plots were segregated between those burned and those not burned in 2005. Plots considered to be burned were those with a cover class of B (at least $5 \%$ charring) or higher and one or more melted Tempilaq paint strips. Plots considered to be unburned in 2005 were those with a charring class of A (no charring) or B (less than $5 \%$ charring), and unmelted Tempilaq paints.

Associated organisms and plot characteristics were analyzed based on two categories of plots: plots in which rare plants were present, termed occupied plots, and plots in which rare plants were absent, termed unoccupied plots. All burned and unburned plots were included in this analysis.

The Lilliefors test was used to determine whether data were normally distributed. Probabilities of differences among treatments were generated with the Kruskal-Wallis statistic to test for differences among burn cover classes and maximum temperatures attained during the burn. Tests for an interaction between year and treatment were generated by comparing the change in burned plots between years and the change in unburned plots between years using the Wilcoxon rank-sum test. The Wilcoxon rank-sum test was also used to test for pairwise differences among burned and unburned plots and habitat characteristics in plots occupied and unoccupied by rare plants.

Percent cover of lichens, moss, unvegetated soil, and Drosera (referred to collectively as "indicators") were thought to be potential indicators of past 
disturbance that may have facilitated the colonization of the NESA core by rare plants. Cover and mean height of both herbaceous and woody plants were referred to collectively as "vegetation characteristics." Correlations between the rare plants and indicators were generated from a Pearson correlation matrix. Regression analyses were completed on woody and herbaceous vegetation and rare plant density, number of inflorescences, and cover, and adjusted coefficients of determination were reported.

Statistical analyses of the rare plant data were completed for Aletris, Platanthera and Polygala (Figure 3). All other species were not conducive to statistical testing due to their extremely low numbers or absence within the NESA core plots. Data on the abundance of these species were generated by active searches within the entire NESA core.

Statistical analyses were completed with SYSTAT software (Wilkinson 1992). 


\section{Results}

\section{Estimated population sizes}

Six of the eight rare species known to exist at the site were documented during the 2005 and 2006 growing seasons (Table 1). Overall, every rare species observed increased in density from 2005 to 2006. Sorghastrum and Aristida were not found within the NESA core despite an active search both years. Spiranthes, while found in 2006, was not observed in the NESA core in 2005. Since data collection began at the site in 1996, estimated populations of all rare plant species have been highly variable between years and between plots within the NESA core (see Appendix B).

\section{Effects of fire within the NESA Core}

Burned plots within the NESA core were subjected to a range of intensity and coverage by the 2005 fire (Table 2). High charring did not necessarily denote a high intensity burn. Maximum temperature attained during the burn and charring cover class had no significant effect on the density, number of inflorescences or percent cover of Aletris, Platanthera, or Polygala in either 2005 or 2006 (P>0.05, KruskalWallis).

In 2005, maximum temperature was significantly related to both mean height of herbaceous plants and the amount of unvegetated soil present, which were both significantly higher in plots reaching $1,000^{\circ} \mathrm{F}$ than in plots reaching all lower temperatures $(\mathrm{P}<0.001$, Kruskal-Wallis). Woody plant cover and mean height were not related to maximum temperatures attained during the burn or by the extent of charring observed in either 2005 or 2006 ( $P>0.05$, Kruskal-Wallis). 
In 2005 and 2006, there was no difference in the density of Aletris, Platanthera, or Polygala between burned and unburned plots $(\mathrm{P}>0.05$; Wilcoxon Rank Sum Test, Figure 4). Density of Aletris inflorescences was significantly higher in unburned plots than in burned plots in both 2005 ( $\mathrm{P}=0.032$; Wilcoxon Rank Sum Test) and 2006 ( $\mathrm{P}=0.016$; Wilcoxon Rank Sum Test, Figure 5). The number of inflorescences of Platanthera in burned plots doubled from 0.7 inflorescences $/ \mathrm{m}^{2}$ in 2005 to 1.4 inflorescences/ $\mathrm{m}^{2}$ in 2006 (Table 3), however, this difference was not statistically significant. In unburned plots, the number of inflorescences of Platanthera was $1.1 / \mathrm{m}^{2}$ in both 2005 and 2006. No significant differences in Polygala flowering were detected between 2005 and 2006 in either burned or unburned plots $(\mathrm{P}>0.05$; Wilcoxon Rank Sum Test, Figure 5).

Percent cover of Aletris followed a similar pattern as the density of Aletris; plots that were unburned had a higher coverage than plots that were burned, however, this difference was not statistically significant (Figure 6). For plots that were burned, the percent cover of Platanthera was higher in 2006 (3.6\% cover) than in 2005 (1.2\% cover; Table 3). Polygala had a relatively low coverage in both burned and unburned plots, and differences were not significant in either year of the study $(P>0.05$ Wilcoxon Rank Sum Test).

Significant year-to-year differences were observed in both the density of Aletris and the percent cover of Platanthera (Table 3). The percent cover of Platanthera and the density of Aletris were both higher in 2006 than in 2005 when averaged across all 61 plots. 
Burned and unburned plots were evaluated for significant differences in the change between years of density of stems, density of inflorescences, and percent cover of Aletris, Platanthera, and Polygala. The between year change in density, number of inflorescences, and percent cover in burned plots was not statistically different from the between year change in unburned plots for Aletris, Platanthera, or Polygala $(\mathrm{P}>0.05$; Wilcoxon Rank Sum test, Figure 7).

Significant differences were observed in the percent cover of Drosera and unvegetated soil in burned and unburned plots in 2005 (Figure 8). The amount of unvegetated soil was significantly higher in burned plots in 2005 than in unburned plots $(\mathrm{P}=0.003$; Wilcoxon Rank Sum Test). However, this effect had disappeared by 2006 , as the amount of unvegetated soil in burned plots ( $10.5 \%$ cover) in 2006 was not statistically different from that in unburned plots in 2005 or 2006 (Table 4). In 2006, Drosera cover in burned plots was not significantly different than in unburned plots (Figure 8). However, in 2005 Drosera cover was significantly higher in unburned plots than in burned plots $(\mathrm{P}=0.024$; Wilcoxon Rank Sum Test). Differences in percent cover of lichens and moss were not significant between any combination of year and treatment $(\mathrm{P}>0.05$; Wilcoxon Rank Sum Test).

The between year decrease in cover of Drosera in unburned plots was significantly greater than the between year decrease in burned plots $(\mathrm{P}=0.01$; Wilcoxon rank sum test, Figure 9). The between year decrease in unvegetated soil in burned plots was significantly different than the between year increase in unburned plots $(\mathrm{P}=0.001$, Wilcoxon Rank Sum Test $)$. 
Herbaceous cover increased more from 2005 to 2006 in burned than in unburned plots $(\mathrm{P}=0.001$; Wilcoxon Rank Sum Test, Figure 9). Herbaceous cover was significantly lower in burned than in unburned plots in $2005(\mathrm{P}=0.001$; Wilcoxon Rank Sum Test), however, that effect had disappeared by 2006 (Figure 10). In burned plots, herbaceous height was significantly higher than in unburned plots during both years of the study $(\mathrm{P}=0.023,2005$ and $\mathrm{P}=0.035,2006$; Wilcoxon Rank Sum Test.

The height of woody plants increased more from 2005 to 2006 in burned than in unburned plots $(\mathrm{P}=0.007$, Wilcoxon Rank Sum Test, Figure 9). For burned plots in 2006 , mean woody plant height $(46.3 \mathrm{~cm})$ was not significantly different from unburned plots in $2005(60.3 \mathrm{~cm})$ and $2006(51.3 \mathrm{~cm}$; Table 4). There was no significant change in woody plant cover between 2005 and 2006, and no difference between burned and unburned plots (Figure 10).

Significant changes were observed between 2005 and 2006 in unvegetated soil, herbaceous plant cover, and woody plant cover when considering all 61 plots within the NESA core (Table 4). The percent cover of woody plants and unvegetated soil significantly decreased from 2005 to 2006 , while the percent cover of herbaceous plants significantly increased from 2005 to 2006 .

Plots categorized as 'not burned' in 2005 were those that were enclosed within sheet metal fire exclosures, or that were unburned simply because the natural course of the fire missed them. The density, cover and number of inflorescences of Aletris, Platanthera, and Polygala in the unburned, unexclosed plots were not significantly different from the unburned, exclosed plots (Table 5). Fire exclosed plots were 
further segregated by those in which shrubs had been cut in 2003 and those that were uncut in 2003. In 2005, the density, cover, and number of inflorescences of Aletris, Platanthera, and Polygala in plots that were cut in 2003 were not significantly different from uncut plots (Table 5). However, in 2006 the number of inflorescences of Platanthera was significantly higher in cut plots than in uncut plots $(\mathrm{P}=0.04$; Wilcoxon Rank Sum Test, Table 5).

Percent cover of unvegetated soil was significantly higher in fire exclosed plots than in unexclosed, unburned plots in both $2005(\mathrm{P}=0.007$; Wilcoxon Rank Sum Test) and $2006(\mathrm{P}=0.039$; Wilcoxon Rank Sum Test, Table 6). In 2006, percent cover of woody plants was significantly lower in fire exclosed plots than in unexclosed, unburned plots $(\mathrm{P}=0.026$; Wilcoxon Rank Sum Test). There were no significant differences in the fire exclosed plots between those that were cut in 2003 and those uncut in 2003 for all vegetation and plot characteristics (Table 6).

Vegetation and habitat characteristics inside the NESA core

The mean percent cover of Drosera, lichens and moss was significantly different in plots occupied by Aletris and Platanthera than in plots unoccupied by those species $(\mathrm{P}<0.01$; Wilcoxon Rank Sum Test, Figure 11). Cover of unvegetated soil did not differ significantly between occupied and unoccupied plots for any of the rare plants. In plots unoccupied by Aletris, mean Drosera and lichen cover was near $0 \%$ in 2005 . The difference in percent cover of Drosera between plots occupied and unoccupied by Aletris was highly significant $(\mathrm{P}<0.001)$ in both 2005 and 2006. The percent cover of woody plants differed significantly between plots occupied and unoccupied by Aletris, but not by those occupied and unoccupied by Platanthera or 
Polygala (Figure 12). In 2006, the mean height of both herbaceous and woody vegetation was significantly lower in plots occupied by either Aletris or Platanthera than in plots unoccupied by these species.

Density of Aletris had a positive relationship with the density of Drosera in $2005(\mathrm{r}=0.73, \mathrm{P}<0.001)$ and $2006(\mathrm{r}=0.57, \mathrm{P}<0.001)$. Density and cover of both Aletris and Platanthera were negatively related to woody plant cover in 2005 and 2006 (Table 7). In 2006, woody cover accounted for $31 \%$ of the variance in Aletris density, and $21 \%$ of the variance in Platanthera density. Aletris density, number of inflorescences and cover all were positively related to herbaceous plant cover (Table 7). Platanthera density and cover were positively related to herbaceous cover. Herbaceous cover explained $30 \%$ of the variance in Aletris density and $21 \%$ in Platanthera density in 2006. Density, cover, and inflorescence abundance in Polygala were not significantly related to the cover of woody or herbaceous plants $(\mathrm{P}>0.05$, data not included $)$.

Platanthera and Aletris density were highly correlated with one another as well as with Drosera density in 2005, however, Polygala density was not correlated with the density of any other rare plant or Drosera (Bartlett Chi-square statistic: 74.727, $\mathrm{df}=6, \mathrm{P}=0.000$ ). Similar results were seen for all three rare plants and Drosera in 2006 (Bartlett Chi-square statistic: 50.106, $\mathrm{df}=6, \mathrm{P}=0.000$ ). None of the rare plants were significantly correlated with any of the other indicator variables which included lichen cover, moss cover, and unvegetated soil cover. The number of plots that contained rare plants did not differ significantly between years $(P>0.05$; 
Wilcoxon Rank Sum), and plots unoccupied by a particular rare plant tended to remain unoccupied for both years of the study (Appendix B).

Effects of fire, shrub cutting, and scarification in the experimental sectors

No rare plants were recorded in newly established plots outside of the NESA core in either 2005 or 2006 . However, treatments had significant effects on other species. Density of the invasive woody vine Celastrus orbiculatus (Oriental bittersweet) was significantly higher in the cut sector in 2006 than in any other sector $(\mathrm{P}<0.001$, Kruskal-Wallis test, Figure 13). In 2006, the density of Celastrus in the cut sector $\left(11.6 \mathrm{stems} / \mathrm{m}^{2}\right)$ was an order of magnitude higher than in the control sector $\left(0.1 \mathrm{stems} / \mathrm{m}^{2}\right)$.

The woody shrub Rhus copallinum (winged sumac) was extremely abundant in the cut and burn sector, and density was significantly higher there than in any other sector (Figure 13). In the cut and burn sector, the density of Rhus remained high in $2006\left(14.4 \mathrm{stems} / \mathrm{m}^{2}\right)$, and like Celastrus in the cut sector, was an order of magnitude higher than in the control $\left(0.4 \mathrm{stems} / \mathrm{m}^{2}\right)$.

The cut sector had the highest cover of herbaceous vegetation (56\%) among all experimental sectors in 2005 (Figure 14). It also had the lowest cover of woody vegetation (30\%), although this was not statistically different from the cut and burn sector. The control sector had higher woody plant cover $(71 \%$, both years) and higher woody plant height (102 $\mathrm{cm}$ in $2005,88 \mathrm{~cm}$ in 2006 ) than all other sectors in both 2005 and 2006. Mean height of herbaceous plants was higher in the control $(54 \mathrm{~cm})$ than in all other sectors except the burn sector in 2005 , however, that difference had disappeared by 2006 (Figure 14). In 2005, the burn sector and the cut and burn sector 
differed significantly in mean height of herbaceous and woody vegetation, however, by 2006 the difference in mean height of woody vegetation was no longer significant. No rare plants were found in the scarified plots established in the cut and burn sector in 2005. In the mowed firebreak that surrounds the site, four Aletris plants were found in 2005, and six Aletris plants were found in 2006. 


\section{Discussion}

\section{Long-term trends in rare plant populations}

Since data collection began at the site in 1996, estimated populations of all rare plant species have experienced large fluctuations from year to year. However, some patterns are evident. For example, the number of inflorescences produced by Platanthera in the NESA core has increased every year since 2003, the year in which the first prescribed burn took place at the site (Keller and Killingbeck 2004). In 2005, the density of Platanthera stems fell to the lowest level since data collection began, yet twice as many inflorescences were produced that year than in 2004. The number of inflorescences produced by Aletris and Polygala, and the density of stems of Polygala peaked in 2004, while the density of Aletris and Platanthera stems peaked in 2003 (Keller and Killingbeck 2004). Such observed fluctuations set in the framework of the experimental treatments implemented in the NESA core have provided insights into the effects of fire on the most abundant of the rare species growing there.

\section{Response of rare plants to fire}

Past studies on geophyte populations and their response to fire have described increases in flowering or aboveground stem production following a burn (Lamont and Runciman 1993, Verboom et al. 2002). Specifically, fire has been utilized to promote flowering in forbs such as Aletris lutea in the southeastern U.S. (Carter et al. 2004, Platt et al. 1988). Such a response from Aletris farinosa at Ninigret was not discerned in 2005 or 2006, as no significant increase in stem density, cover, and number of inflorescences of Aletris was detected in burned plots. 
The extent and timing of the burn in 2005 may offer explanations as to why Aletris did not respond positively to this treatment. It is possible that the fire was applied too late in the growing season for Aletris to respond in 2005. At the time of the May burn, the basal rosettes of the plant were already above ground and it may have been too late for the plants to immediately benefit from the effects of the fire. Charring was observed on the basal rosettes of some Aletris stems, but such charring was minimal and it did not seem as though these individuals were killed by the burn.

It is likely that a combination of both uneven distribution of the fire relative to the distribution of the plants within the NESA core and the timing of the burn contributed to the lack of an increase of Aletris in burned plots during this study.

The high heterogeneity influenced the ability to determine significant changes in Platanthera as a result of the burning treatment. The increases in reproductive output and percent cover of Platanthera were not statistically significant, however, trends overall suggest that burning may have had a positive effect. This would support similar results in other investigations in the response of rare orchids to fire (Norton and Delange 2003, Wotavova et al. 2004). Like Aletris, Platanthera is a geophyte with underground storage for future growth and reproduction. It is believed that disturbances such as fire can stimulate growth and reproduction in orchids (Stuckey 1967, Whelan 1995). Due to the high incidence of rarity in the family Orchidaceae, not only in New England (Brumback and Mehrhoff 1996, Enser 2002) but also in many other parts of the world (Kirkpatrick and Gilfedder 1995, Lunt 1997, Silvertown et al. 1994), the suggestion that fire may stimulate reproductive output is an important consideration. 
Fire did not have any statistically significant effects on the stem density, cover or inflorescence production of Polygala cruciata. Of the 61 plots within the NESA core, only 10 plots in 2005, and 14 plots in 2006 were occupied by Polygala. This low density, coupled with high variability in the dataset, made it difficult to detect relationships between Polygala and other rare plants and associated organisms at the site. However, trends point toward higher densities of Polygala in burned plots and further study may be important in understanding these trends.

Research on fire and rare plants has been increasing since the 1980's and more rapidly since the early 1990's (Hassl and Spackman 1995). Such research is vital to the conservation of some rare plant populations and fire is a recommended tool for increasing rare plant populations (Jacobson et al. 1991), yet it is difficult to elucidate effects without long-term monitoring of at least three years (Menges 1986). The best course of action toward the recovery of an endangered plant species is a comprehensive management plan that asseses the biological status and demographics of the plant in question, and also includes guidelines for management and recovery (Schemske et al. 1994). Presently, one such plan exists for Platanthera (Sharp 2004). Once found in greater numbers in New England, only 10 extant sites with populations of Platanthera still remain (out of 41 historic populations). Of the 10 populations still considered extant in New England, two are relatively stable, two have shown decline, and six have not been found in recent surveys (Sharp 2004). Fire may be an important tool in efforts to restore vigor to those populations facing extirpation. Response of NESA core vegetation to fire 
In examining the effects of fire on the herbaceous and woody vegetation inside the NESA core, it was apparent that the burn did not reduce cover of woody plants or height of herbaceous plants. Differences that were observed in burned plots, specifically cover of herbaceous plants and height of woody plants, were short-lived. By the year after the burn, cover of herbaceous plants and height of woody plants had both increased to effectively negate the differences observed in 2005 after the burn. This suggests that the fire did not kill a significant amount of the woody plants inside the NESA core. Results from this study and others (Briggs et al. 2002, Glasgow and Matlack 2007, Heisler et al. 2003) suggest that responses of woody shrubs to fire are much weaker by the second year after a prescribed burn, necessitating a continuation of prescribed fire if long-term reductions in woody vegetation are a goal.

Legacy effects from shrub-cutting treatments in fire exclosed plots in 2003 were not significant in 2005 or 2006 for herbaceous or woody vegetation. This suggests that the shrub cutting treatments, which were applied once before the initiation of this study, were not effective in controlling coverage or height of the vegetation inside the NESA core in the long-term. Others have observed this effect after shrub-cutting treatments were applied in an effort to reduce competition between rare plants and competing vegetation (Barbaro et al. 2001, Gordon 1996, Muller 2002). However, the mean height of the vegetation was significantly lower in the unburned plots than in the burned plots, despite the fact that no past treatments had taken place in 13 of the unburned plots. This limited the ability to test for differences between burned and unburned plots within the NESA core, as these groups were inherently different before the treatment was applied. The fact that the differences 
existed despite the fact that no manipulations had occurred in many of the unburned plots gives merit to the theory that disturbance history has played a role in the present day distribution of plants and habitat characteristics at the site.

Trends in vegetation and habitat characteristics in the NESA core

Discovering what makes a particular environment suitable for the rare plants that inhabit it has always been a challenge (Clarke and Patterson 2006, Motzkin and Foster 2002, Schemske et al. 1994). Certain habitat variables were important in determining whether or not rare plant species grew in a particular plot within the NESA core. Coverage and stem density of Drosera was highly correlated with, and had significant, positive relationships with the density of stems of both Aletris and Platanthera. In 2005 and 2006, nearly all plots that contained Aletris contained Drosera as well. The presence of Drosera is indicative of disturbed, nutrient poor environments (Brewer 1999) and slightly acidic, hydric environments (Juniper et al. 1989). Such environmental characteristics may be important for the establishment, growth, or persistence of Aletris and Platanthera.

Overall, plots containing $40-50 \%$ cover of herbaceous plants and less than $30-$ $40 \%$ cover of woody plants were most likely to have at least one rare plant species growing in them. Both Aletris and Platanthera had positive relationships with cover of herbaceous plants and negative relationships with cover of woody plants. These trends underscore the potential influence of common species on the abundance and distribution of rare species.

It has been observed that light limitations and competitive interactions with surrounding species have been important in excluding many orchid species from sites 
in which they have occurred historically (Wotavova et al. 2004). At Ninigret, there was no difference in percent cover of woody vegetation in plots that were occupied by Platanthera than in plots that were not occupied by Platanthera. This suggests that the mere presence of woody vegetation did not preclude the presence of Platanthera. However, the mean height of the woody vegetation was significantly lower in plots that were occupied by Platanthera than in plots that were not occupied by Platanthera. This result supports the theory that disturbances which limit the height of surrounding vegetation, including certain historic management regimes, are vital to the persistence of the rare orchid species found within disturbed sites (Lunt 1997).

Whether woody or herbaceous, the mean height of vegetation in plots containing rare plants in 2005 was less than $25-35 \mathrm{~cm}$, which was not significantly different from the mean height of the entire NESA core in 2005. In 2006 the mean height of vegetation in plots containing rare plants $(30-40 \mathrm{~cm})$ was lower than the mean height of vegetation at the site overall. The increase in height of woody plants in 2006 in burned plots may have contributed to this difference. However, relationships between Aletris, Platanthera, and Polygala and mean height of the surrounding vegetation were weak or non-existent in 2006 . Consequently, impacts from the increase in height of the woody vegetation were not detected. Impacts may be observed in the future if significant increases in height of the vegetation continue because local extinctions of orchid species apparently caused by increasing levels of shade have occurred in other parts of Rhode Island (Stuckey 1967). 
The properties of the soil inside the NESA core are most likely one of the keys to explaining the unique nature of the NESA core. For example, the presence of Drosera is indicative of recently disturbed habitats with high light availability and low soil fertility (Brewer 1999, Givnish et al. 1984). The tight association between Drosera and both Aletris and Platanthera may be a function of both high light and low fertility. Both Platanthera and Scleria sp. were associated with nutrient poor environments in conservation plans for each species (Sharp 2004, Zaremba 2004). In addition, organic matter in the soil of the NESA core was $50 \%$ lower than in areas adjacent to the NESA core (Killingbeck et al. 1998).

The extended persistence of shrubs growing at abnormally low heights has been suggested to indicate the presence of an environmental limiting factor (Latham 2003). Woody shrubs are a major component of the NESA core, yet many are low growing and do not prevent the co-occurrence of rare plants. Some plots within the NESA core harbor low-growing herbaceous and woody plants that have been unaltered by experimental manipulations and of these plots, many contain high densities of Aletris and Platanthera. Therefore, it is possible that the soil fertility limited the growth of herbaceous and woody vegetation thus allowing high light penetration. This in turn may have produced optimal conditions for the rare plants that exist in the NESA core.

Treatment effects outside of the NESA core

The manipulations implemented in the shrub-dominated area outside the NESA core did not promote rapid colonization by any of the rare plants. However, the treatments did have major impacts on other species. The cut treatment clearly 
facilitated the growth of Celastrus orbiculatus, an invasive woody vine. Reductions in the cover of tall shrubs caused by the treatment most likely promoted the increase in density and cover of Celastrus. Disturbances, in general, contribute to the spread of Celastrus by increasing light availability and reducing competition for resources (McNab and Loftis 2002). Greenberg et al. (2001) have proposed a "sit and wait" strategy for the mechanism by which Celastrus establishes and spreads. This strategy involves growing and persisting within an undisturbed, closed canopy until a disturbance opens up the canopy, allowing for rapid growth and proliferation (Greenberg et al. 2001).

The introduction of disturbance to the experimental sectors initiated a rapid increase in growth of Celastrus and clearly indicates that cutting shrubs in the absence of fire may contribute to future increases in this nonnative species. Studies suggest Celastrus will spread rapidly after a sufficient disturbance (Silveri et al. 2001) and can be highly correlated with scarified, exposed soils (McNab and Loftis 2002, Silveri et al. 2001). Celastrus has a rapid, prolific, and consistent annual rate of production of seeds that have both high viability and high germination rates (Ellsworth et al. 2004). The rapid response of Celastrus to the cut treatment indicates that buried seeds were likely the source of the increase in density. Celastrus seeds are thought to be spread primarily by birds (McNab and Loftis 2002), and the source of the seeds could have come from other parts of the NNWR that support mature Celastrus plants. A significant increase in Celastrus stem density in 2006 suggests that the growth and spread of this invasive could continue and eventually impact the adjacent NESA core if it is not controlled. 
Rather than promoting the growth of Celastrus, the adjacent experimental sector that was both cut and burned was immediately dominated by Rhus copallinum after the 2005 burn. Rhus demonstrated the same rapid growth and colonization in response to the cut and burn treatment as Celastrus did to the cut treatment, despite the fact that Celastrus is invasive to Rhode Island and Rhus is a native woody shrub. Some shrub species are typically the first to grow back after disturbance due to their ability to re-sprout and spread by rhizomes (Glasgow and Matlack 2007).

Consequently, plant species with clonal growth forms are common in many disturbed habitats (Hartnett 1987). Although it is unknown whether the profusion of Rhus was primarily from seed germination or re-growth from rhizomes, the very low densities of Rhus in the control sector suggest that germination from seed may have been a major source of this species in the cut and burned sector.

The lack of Celastrus stems in the cut and burn sector is difficult to explain. There seems to be no published literature focused on the effects of fire on Celastrus, but in this study, the differences in Celastrus density between the burned sectors and the cut-only sector suggest that fire may have a negative impact on this species. One possible mechanism for such an effect would be a reduction in seed viability caused by high temperatures.

While major differences in the cover of woody plants between burned and unburned plots did not occur in the NESA core, major differences were found in the experimental sectors. By the 2006 growing season, the percent cover and height of woody plants had not reached the pre-burn levels of the control. While differences existed in 2005 between the cut, cut and burn, and burn sectors, these three sectors 
were no different from each other by 2006 . This suggests that the preliminary cut treatment applied immediately before the burn treatment in the cut and burn sector was not effective in controlling woody plants any more than the burn only treatment, by 2006 . Also, the application of the cut treatment before the burn may have promoted the proliferation of Rhus in the cut and burn sector, since the high densities of Rhus were not seen in the burn only sector.

The scarified plots introduced into the cut and burn sector had no immediate impact on rare plant growth or establishment. However, it is possible that such growth may take longer than the two growing seasons of the study.

\section{Management implications}

Continued prescribed burning is recommended inside the NESA core. Scheduling of a future burn should occur, if possible, before Aletris emerges at the site to see if a difference in timing of the burn would have a more positive effect on Aletris. While no positive effects on the rare plants were detected statistically in response to the 2005 burn, it also does not appear that they were negatively impacted by burning.

Woody plant cover may have negative impacts on both Aletris and Platanthera inside the NESA core. Continued management of the site should attempt to reduce woody plant cover, especially in plots containing over $35 \%$ cover of woody plants. While no significant relationships were detected between Aletris, Platanthera, and Polygala and mean height of the surrounding vegetation inside the NESA core, trends show important distinctions in the height of vegetation between those plots that were occupied by rare plants and those that were not. Continued prescribed burning 
inside the NESA core is recommended, however, large-scale mechanical shrub cutting by itself is not recommended due to the potential for increasing Celastrus density inside the NESA core. Small-scale shrub-cutting treatments applied by hand may help to curb woody plant growth, possibly during years in which fire is not applied. However, cutting treatments should be applied in one to two year intervals since this study has shown that effects on shrubs over two years after a cutting treatment are negligible.

This study has documented that Celastrus density has increased dramatically in response to shrub cutting. This treatment was aimed at managing rare and endangered plants at NNWR, instead, the shrub cutting treatment may now put rare plants in jeopardy if the Celastrus is not controlled. Great care must be taken to identify the best possible management strategies that concurrently limit the proliferation of the invasive Celastrus and promote growth and flowering of the rare plants. While no significant rare plant growth occurred outside of the NESA core, such a result may take longer than the two growing seasons of the study, and future prescribed burning in areas immediately adjacent to the NESA core is recommended. 
Table 1

Estimated population sizes for rare species and Drosera in the NESA core $\left(2,300 \mathrm{~m}^{2}\right)$.

Numbers for both Scleria species and Spiranthes were generated from an

active search, while numbers for all other plants were extrapolated from plot data.

Sorghastrum nutans and Aristida longespica were not found in the NESA core

in either year, and Spiranthes tuberosa was not found in the NESA core in 2005.

\begin{tabular}{llrr}
\hline & & 2005 & 2006 \\
\hline Aletris farinosa & & 28,807 & 33,481 \\
& stems & 2,187 & 1,961 \\
Platanthera ciliaris & inflorescences & 15,082 & 26,620 \\
& stems & 1,961 & 3,016 \\
Polygala cruciata & inflorescences & & 16,666 \\
& stems & 15,157 & 6,108 \\
Scleria paucifiora & inflorescences & 10,256 & 4,859 \\
& & & 2,652 \\
Scleria triglomerata & inflorescences & 3,224 & 841 \\
& & 1,855 & 407 \\
Spiranthes tuberosa & stems & 698 & 55 \\
& inflorescences & 310 & 55 \\
Drosera spp. & stems & - & 272,380 \\
& inflorescences & - & 145,239 \\
\hline
\end{tabular}


Table 2

Range of maximum temperatures reached in NESA core plots that were

burned in 2005 and the number of plots within the NESA core for which

those temperatures were reached. Charring range indicates the mean

range of charring that occurred at each maximum temperature. Numbers

in paranthesis are standard errors for mean charring range.

\begin{tabular}{rcl}
\hline $\begin{array}{l}\text { maximum } \\
\text { temp. reached }\end{array}$ & $\begin{array}{l}\text { \# of plots } \\
\text { reaching } \\
\text { each temp. }\end{array}$ & $\begin{array}{l}\text { mean charring } \\
\text { class }\end{array}$ \\
\hline No Melting & 8 & $43-62 \%(8)$ \\
$200^{\circ} \mathrm{F}$ & 8 & $61-78 \%(12)$ \\
$400^{\circ} \mathrm{F}$ & 8 & $78-97 \%(3)$ \\
$600^{\circ} \mathrm{F}$ & 3 & $80-99 \%(0)$ \\
$800^{\circ} \mathrm{F}$ & 7 & $80-99 \%(0)$ \\
$1000^{\circ} \mathrm{F}$ & 3 & $67-86 \%(7)$ \\
\hline
\end{tabular}


Table 3: Mean density of stems, density of inflorescences, and \% cover for Aletris, Platanthera, and Polygala in all 61 plots in the NESA core (first set of paired rows). Plots were further broken down by treatment type based on whether they were burned in 2005 (middle set of paired rows) or unburned in 2005 (last set of paired rows). The number of plots in each dataset is indicated in parenthesis in the left-hand column. Significant differences for all NESA core plots between years are indicated by asterisks $\left({ }^{\star} P<0.05,{ }^{* *} \mathrm{P}<0.01\right)$. Significant differences between treatments are shown in Figures 4-6. Standard error of the mean is given in parenthesis.

\begin{tabular}{|c|c|c|c|c|c|c|c|c|c|c|}
\hline & year & stems $/ \mathrm{m}^{2}$ & $\begin{array}{c}\text { Aletris } \\
\text { Inflorescences } / \mathrm{m}^{2}\end{array}$ & $\%$ cover & stems $/ \mathrm{m}^{2}$ & $\begin{array}{c}\text { Platanthera } \\
\text { inflorescences } / \mathrm{m}^{2}\end{array}$ & $\%$ cover & stems $/ \mathrm{m}^{2}$ & $\begin{array}{c}\text { Polygala } \\
\text { Inflorescences } / \mathrm{m}^{2}\end{array}$ & $\%$ cover \\
\hline \multirow{2}{*}{ Core Plots (61) } & 2005 & $12.5(1.3)$ & $0.9(0.2)$ & $5.3(1.2)$ & $6.6(0.5)$ & $0.9(0.1)$ & $1.6(0.4)$ & $6.6(1.4)$ & $4.5(0.9)$ & $0.5(0.2)$ \\
\hline & 2006 & 14.5 (1.3) & $0.8(0.2)$ & $4.7(1.1)$ & $11.3(0.7)^{\star \star}$ & $1.3(0.1)$ & $3.5(0.6)^{*}$ & $7.6(1.1)$ & $2.7(0.5)$ & $0.3(0.1)$ \\
\hline $\begin{array}{l}\text { Burned in } 2005 \\
\text { (37) }\end{array}$ & $\begin{array}{l}2005 \\
2006\end{array}$ & $\begin{array}{l}8.1(1.2) \\
9.5(1.3)\end{array}$ & $\begin{array}{l}0.3(0.1) \\
0.6(0.2)\end{array}$ & $\begin{array}{l}2.7(0.8) \\
3.0(1.0)\end{array}$ & $\begin{array}{r}5.5(0.6) \\
10.7(0.9)\end{array}$ & $\begin{array}{l}0.7(0.1) \\
1.4(0.2)\end{array}$ & $\begin{array}{l}1.2(0.3) \\
3.6(0.9)\end{array}$ & $\begin{array}{l}9.1(2.2) \\
9.4(1.6)\end{array}$ & $\begin{array}{l}5.7(1.4) \\
3.3(0.8)\end{array}$ & $\begin{array}{l}0.6(0.3) \\
0.5(0.2)\end{array}$ \\
\hline $\begin{array}{l}\text { Unburned in } \\
2005 \text { (24) }\end{array}$ & $\begin{array}{l}2005 \\
2006\end{array}$ & $\begin{array}{l}19.3(2.5) \\
22.3(2.6)\end{array}$ & $\begin{array}{l}1.9(0.4) \\
1.3(0.3)\end{array}$ & $\begin{array}{l}9.2(2.5) \\
7.4(2.1)\end{array}$ & $\begin{array}{r}8.3(1.0) \\
12.4(1.2)\end{array}$ & $\begin{array}{l}1.1(0.2) \\
1.1(0.2)\end{array}$ & $\begin{array}{l}2.3(0.7) \\
3.3(0.7)\end{array}$ & $\begin{array}{l}2.7(0.8) \\
4.8(1.4)\end{array}$ & $\begin{array}{l}2.6(0.8) \\
1.7(0.6)\end{array}$ & $\begin{array}{l}0.3(0.2) \\
0.2(0.1)\end{array}$ \\
\hline
\end{tabular}


Table 4: Mean density and/or cover for Drosera, lichens, unvegetated soil ('unveg'), moss, herbaceous and woody plants in all 61 plots in the NESA core (first set of paired rows). Plots were further broken down by treatment type based on whether they were burned in 2005 (middle set of paired rows) or unburned in 2005 (last set of paired rows). The number of plots in each dataset is indicated in parenthesis in the left-hand column. Significant differences for all NESA core plots between years are indicated by asterisks $\left({ }^{*} P<0.05,{ }^{* *} \mathrm{P}<0.01\right)$. Significant differences between treatments are shown in Figures 7-8. Standard error of the mean is given in parenthesis.

\begin{tabular}{|c|c|c|c|c|c|c|c|c|c|c|}
\hline & \multirow[b]{2}{*}{ year } & \multicolumn{2}{|c|}{ Drosera } & \multirow{2}{*}{$\begin{array}{l}\text { lichens } \\
\% \text { cover } \\
\end{array}$} & \multirow{2}{*}{$\begin{array}{l}\text { unveg } \\
\% \text { cover }\end{array}$} & \multirow{2}{*}{$\begin{array}{l}\text { moss } \\
\% \text { cover }\end{array}$} & \multicolumn{2}{|c|}{ herbaceous plants } & \multicolumn{2}{|l|}{ woody plants } \\
\hline & & stems $/ \mathrm{m}^{2}$ & $\%$ cover & & & & $\%$ cover & mean helght (cm) & $\%$ cover & mean helght $(\mathrm{cm})$ \\
\hline \multirow{2}{*}{ Core Plots (61) } & 2005 & $25.5(6.6)$ & $2.3(0.7)$ & $1.5(0.6)$ & $14.2(1.7)$ & $4.3(1.3)$ & $37.7(2.9)$ & $34.4(2.6)$ & $44.8(2.9)$ & $46.8(5.6)$ \\
\hline & 2006 & $59.1(12.2)$ & $1.1(0.2)$ & $1.3(0.5)$ & $9.7(1.2)^{*}$ & $4.9(0.9)$ & $50.6(3.4)^{\text {** }}$ & $32.3(2.1)$ & $38.9(3.3)^{* * *}$ & $48.3(2.9)$ \\
\hline $\begin{array}{l}\text { Burned in } 2005 \\
\text { (37) }\end{array}$ & $\begin{array}{l}2005 \\
2006\end{array}$ & $\begin{array}{l}25.2(4.7) \\
84.1(11.9)\end{array}$ & $\begin{array}{l}1.0(0.4) \\
0.9(0.3)\end{array}$ & $\begin{array}{l}1.4(0.7) \\
1.3(0.7)\end{array}$ & $\begin{array}{l}19.2(2.3) \\
10.5(1.5)\end{array}$ & $\begin{array}{l}4.8(2.1) \\
5.3(1.4)\end{array}$ & $\begin{array}{l}29.1(2.6) \\
47.9(3.8)\end{array}$ & $\begin{array}{l}39.3(3.5) \\
35.5(2.9)\end{array}$ & $\begin{array}{l}46.8(3.3) \\
39.9(3.5)\end{array}$ & $\begin{array}{l}38.1(2.3) \\
46.3(2.8)\end{array}$ \\
\hline $\begin{array}{l}\text { Unburned in } 2005 \\
\text { (24) }\end{array}$ & $\begin{array}{l}2005 \\
2006\end{array}$ & $\begin{array}{r}90.7(14.7) \\
170.9(24.8)\end{array}$ & $\begin{array}{l}4.5(1.5) \\
1.3(0.4)\end{array}$ & $\begin{array}{l}1.8(1.1) \\
1.4(0.7)\end{array}$ & $\begin{array}{l}6.5(1.7) \\
8.3(2.2)\end{array}$ & $\begin{array}{l}3.6(1.2) \\
4.3(0.9)\end{array}$ & $\begin{array}{l}51.0(5.2) \\
54.6(6.4)\end{array}$ & $\begin{array}{l}26.7(3.5) \\
27.3(2.6)\end{array}$ & $\begin{array}{l}41.7(5.6) \\
37.3(6.6)\end{array}$ & $\begin{array}{l}60.3(13.5) \\
51.3(6.4)\end{array}$ \\
\hline
\end{tabular}


Table 5: Mean density, inflorescences, and \% cover of Aletris, Platanthera, and Polygala in plots that were not burned in 2005. Both the 2005 and 2006 datasets for unburned plots were categorized based on the presence or absence of a metal exclosure deployed before the 2005 burn. The plots that were exclosed were categorized based on whether they were cut or uncut in 2003. The number of plots in each dataset is indicated in parenthesis in the left-hand column. Significant differences in pairwise comparisons are indicated by asterisks $\left({ }^{*} \mathrm{P}<0.05\right)$. All other pairwise relationships between paired rows are not significant. Standard error of the mean is given in parenthesis.

\begin{tabular}{|c|c|c|c|c|c|c|c|c|c|}
\hline & stems $/ \mathrm{m}^{2}$ & $\begin{array}{c}\text { Aletris } \\
\text { inflorescences } / \mathrm{m}^{2}\end{array}$ & $\%$ cover & stems $/ \mathrm{m}^{2}$ & $\begin{array}{c}\text { Platanthera } \\
\text { Inflorescences } / \mathrm{m}^{2}\end{array}$ & $\%$ cover & stems $/ \mathrm{m}^{2}$ & $\begin{array}{c}\text { Polygala } \\
\text { Inflorescences } / \mathrm{m}^{2}\end{array}$ & $\%$ cover \\
\hline \multicolumn{10}{|l|}{2005} \\
\hline Unexclosed plots (11) & $16.2(3.9)$ & $2.9(0.7)$ & $9.1(4.0)$ & $9.6(2.1)$ & $1.5(0.4)$ & $3.0(1.5)$ & $1.1(0.5)$ & $0.9(0.5$ & $0.1(0.1)$ \\
\hline Fire exclosed plots (13) & 22.0 & $1.1(0.2)$ & $9.3(3.4)$ & $7.1(0.7)$ & $0.8(0.2)$ & $1.7(0.5)$ & $4.0(1.5)$ & $4.0(1.5)$ & $0.5(0.4)$ \\
\hline cut in 2003 (6) & $19.0(4.6)$ & $1.0(0.3)$ & $5.2(2.3)$ & $7.7(1.2)$ & $1.3(0.3)$ & $1.5(0.7)$ & $0.0(0.0)$ & $0.0(0.0)$ & $0.0(0.0)$ \\
\hline uncut In 2003 (7) & $24.6(4.9)$ & $1.1(0.3)$ & $12.9(5.8)$ & $6.6(0.9)$ & $0.3(0.1)$ & $1.9(0.8)$ & $7.4(2.6)$ & $7.5(2.6)$ & $0.9(0.7)$ \\
\hline \multicolumn{10}{|l|}{2006} \\
\hline Unexclosed plots (11) & $20.7(3.9)$ & $1.6(0.6)$ & $10.5(4.2)$ & $11.5(1.9)$ & $1.3(0.4)$ & $3.7(1.3)$ & $5.5(2.1)$ & $2.5(1.3)$ & $0.2(0.1)$ \\
\hline Fire exclosed plots (13) & $27.8(3.6)$ & $1.1(0.2)$ & $5.6(1.6)$ & $14.6(1.7)$ & $0.9(0.2)$ & $3.2(0.8)$ & $5.1(2.0)$ & $1.1(0.4)$ & $0.2(0.1)$ \\
\hline cut in 2003 (6) & $20.7(4.6)$ & $0.3(0.2)$ & $4.3(1.9)$ & $11.7(1.6)$ & $1.7(0.3)$ & $2.3(0.8)$ & $8.0(4.0)$ & $0.7(0.3)$ & $0.2(0.2)$ \\
\hline uncut in 2003 (7) & $26.3(5.6)$ & $1.4(0.4)$ & $5.1(2.4)$ & $14.6(2.7)$ & $0.3(0.1)^{*}$ & $3.3(1.4)$ & $1.1(0.6)$ & $1.1(0.6)$ & $0.1(0.1)$ \\
\hline
\end{tabular}


Table 6: Mean density, cover, and/or height for all other organisms and habitat variables sampled in plots that were not burned in 2005 . Both the 2005 and 2006 datasets for unburned plots were categorized based on the presence or absence of the metal exclosure deployed before the 2005 burn. The plots that were exclosed were categorized based on whether they were cut or uncut in 2003 . The number of plots in each dataset is indicated in parenthesis in the left-hand column. Significant differences in pairwise comparisons are indicated by asterisks ( $\left.{ }^{\star} \mathrm{P}<0.05,{ }^{* *} \mathrm{P}<0.01\right)$. All other pairwise relationships between paired rows are not significant. Standard error of the mean is given in parenthesis.

\begin{tabular}{|c|c|c|c|c|c|c|c|c|c|}
\hline & \multicolumn{2}{|c|}{ Drosera } & \multirow{2}{*}{$\begin{array}{l}\text { Lichen } \\
\% \text { cover } \\
\end{array}$} & \multirow{2}{*}{$\begin{array}{l}\text { Unveg } \\
\% \text { cover }\end{array}$} & \multirow{2}{*}{$\begin{array}{l}\text { Moss } \\
\% \text { cover }\end{array}$} & \multicolumn{2}{|c|}{ Herbaceous plants } & \multicolumn{2}{|c|}{ Woody plants } \\
\hline & stems $/ \mathrm{m}^{2}$ & $\%$ cover & & & & $\%$ cover & mean height (cm) & $\%$ cover & mean height $(\mathrm{cm})$ \\
\hline \multicolumn{10}{|c|}{ (2) } \\
\hline Unexclosed plots (11) & $84.0(26.4)$ & $3.8(2.7)$ & $1.0(0.9)$ & $0.9(0.6)$ & $3.3(1.5)$ & $49.1(9.0)$ & $18.4(2.8)$ & $50.0(9.1)$ & $77.5(26.7)$ \\
\hline Fire exclosed plots (13) & $96.5(16.5)$ & $5.1(1.6)$ & $2.5(1.9)$ & $11.2(2.5)^{* *}$ & $3.9(1.9)$ & $52.7(6.1)$ & $33.8(5.4)$ & $34.6(6.7)$ & $45.6(10.0)$ \\
\hline $\begin{array}{l}\text { cut in } 2003 \text { (6) } \\
\text { uncut in } 2003 \text { (7) }\end{array}$ & $\begin{array}{r}122.0(31.0) \\
74.6(14.8)\end{array}$ & $\begin{array}{l}5.2(2.3) \\
5.0(2.2)\end{array}$ & $\begin{array}{l}4.9(3.7) \\
0.1(0.1)\end{array}$ & $\begin{array}{l}10.8(3.6) \\
11.4(3.4)\end{array}$ & $\begin{array}{l}1.8(0.9) \\
5.7(3.4)\end{array}$ & $\begin{array}{l}54.2(5.5) \\
51.4(10.6)\end{array}$ & $\begin{array}{l}35.8(7.1) \\
32.1(8.1)\end{array}$ & $\begin{array}{l}31.7(7.4) \\
37.1(10.7)\end{array}$ & $\begin{array}{l}35.5(4.8) \\
54.3(18.1)\end{array}$ \\
\hline \multicolumn{10}{|l|}{2006} \\
\hline Unexclosed plots (11) & $94.8(29.4)$ & $1.0(0.6)$ & $0.1(0.1)$ & $4.1(1.1)$ & $4.2(1.1)$ & $44.1(10.3)$ & $23.2(3.6)$ & $51.4(10.3)$ & $60.0(11.5)$ \\
\hline Fire exclosed plots (13) & $230.0(36.9)$ & $1.7(0.6)$ & $2.5(1.3)$ & $11.8(3.9)^{*}$ & $5.1(1.5)$ & $66.4(6.8)$ & $27.7(3.1)$ & $22.7(7.1)^{*}$ & $44.5(6.9)$ \\
\hline cut in $2003(6)$ & $175.0(41.6)$ & $0.7(0.2)$ & $4.3(2.3)$ & $14.2(6.4)$ & $3.5(1.6)$ & $65.8(7.1)$ & $31.7(4.8)$ & $21.7(7.9)$ & $38.3(6.3)$ \\
\hline uncut in 2003 (7) & $288.6(60.0)$ & $2.3(0.9)$ & $0.9(0.7)$ & $10.0(4.5)$ & $5.0(2.4)$ & $61.4(13.0)$ & $30.0(5.5)$ & $28.6(12.3)$ & $48.6(10.7)$ \\
\hline
\end{tabular}


Table 7: Adjusted coefficients of determination from regression analyses describing the relationships between $\%$ cover and height of both woody and herbaceous plants and percent cover, density $\left(\mathrm{stems} / \mathrm{m}^{2}\right)$, and inflorescence abundance (inflorescences/m2) of Aletris and Platanthera. All relationships with woody plant cover were negative, all relationships with herbaceous plant cover were positive, and all relationships with mean height of both woody and herbaceous plants were negative. $\mathrm{N}=61$ throughout.

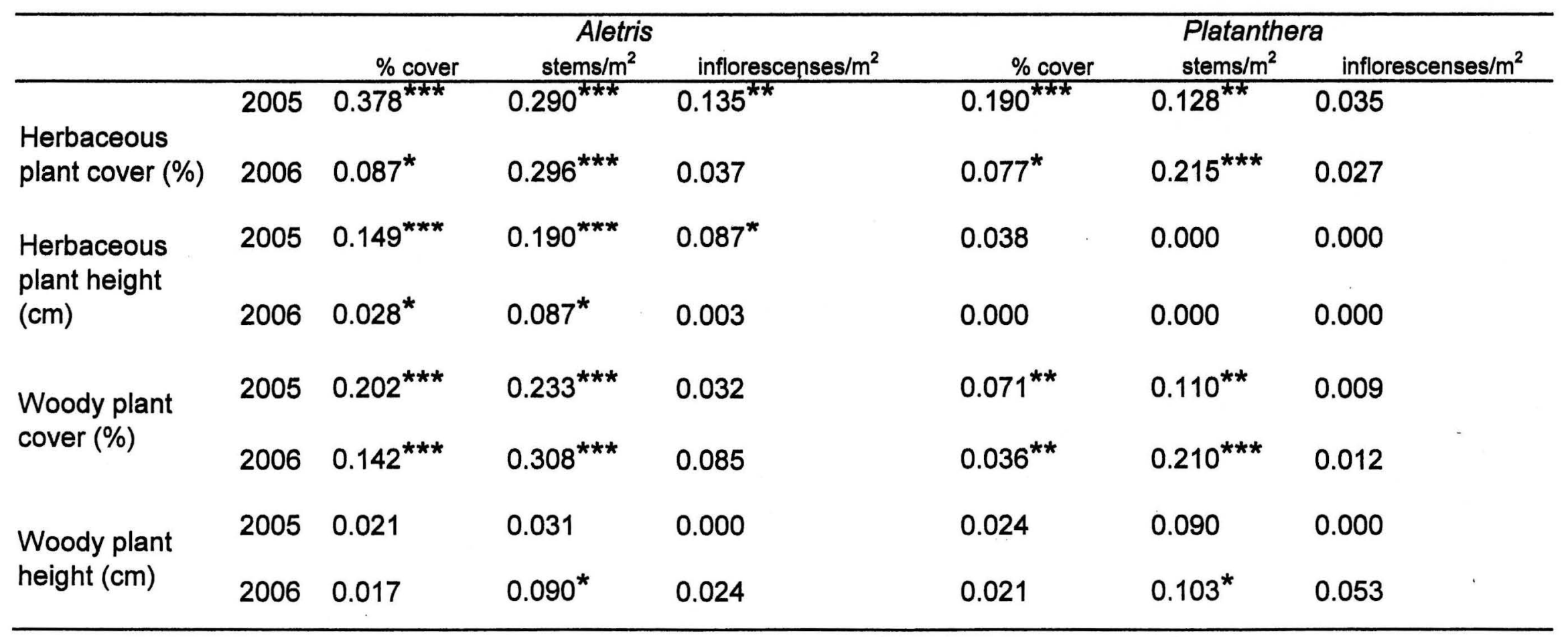




\section{Ninigret Endangered Species Area}

NESA core and experimental sectors

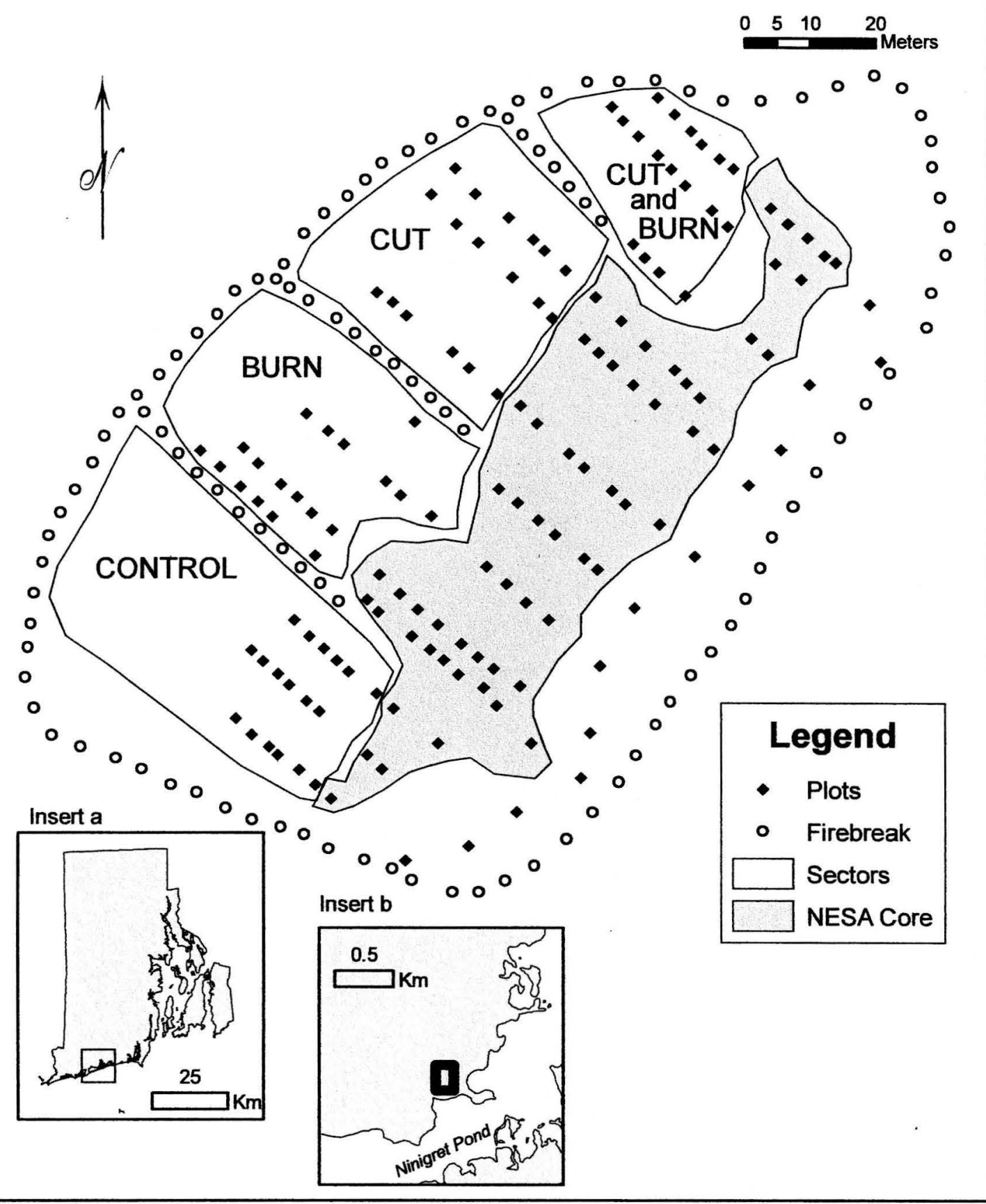

Figure 1: Map of the study area indicating the location of the NESA Core and the four experimental sectors adjacent to the Core Insert a: location of study area within RI Insert b: close up of the study area adjacent to Ninigret Pond 


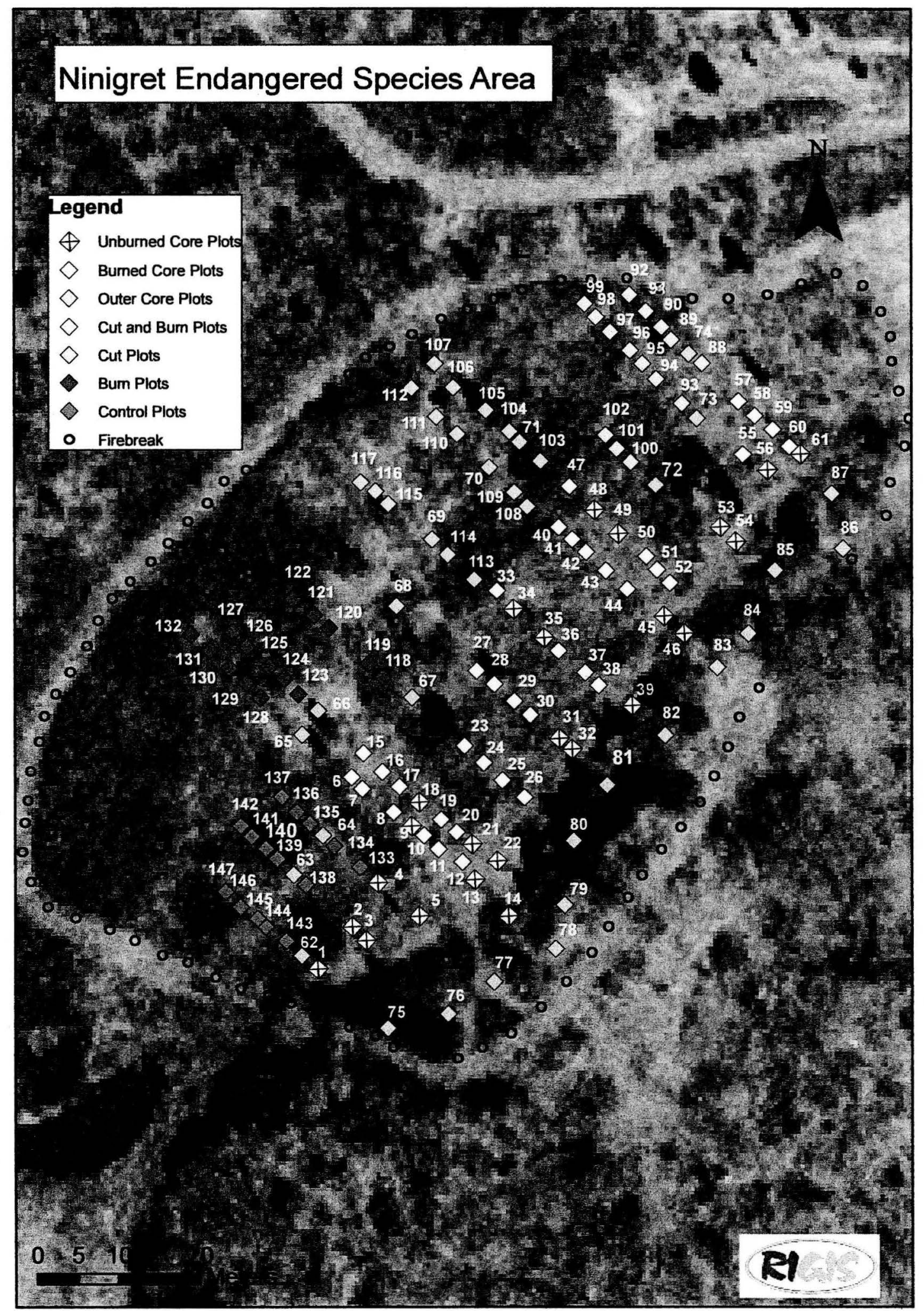

Figure 2: Plot numbers and designations for all 147 plots (with 2003-04 RIDOT Orthophoto) 


\section{Platanthera ciliaris}

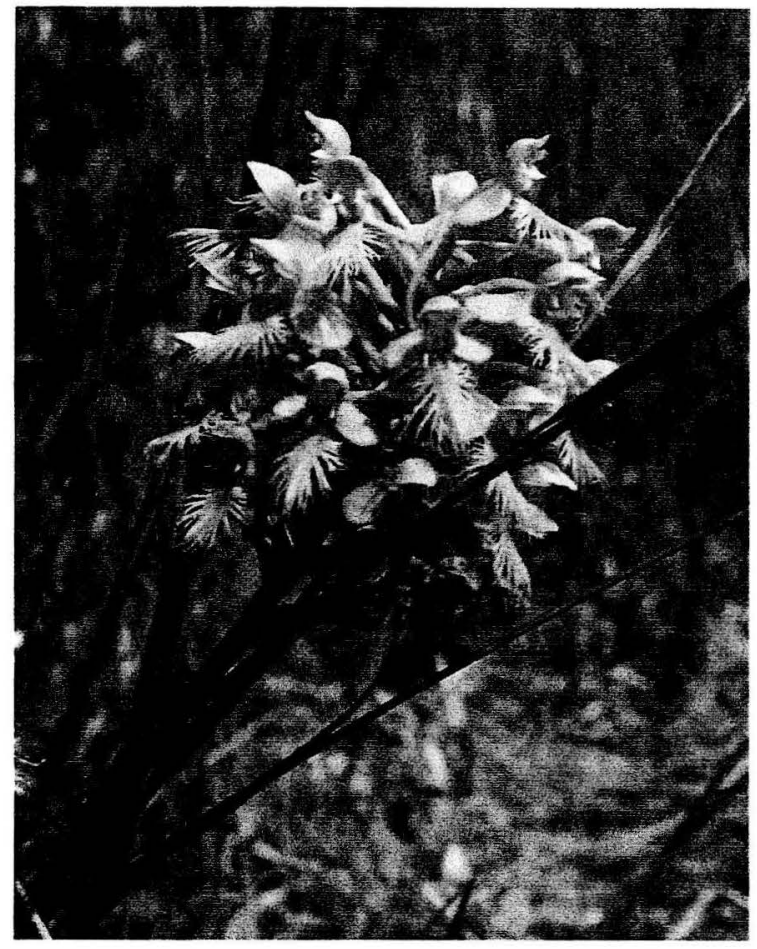

\section{Polygala cruciata}

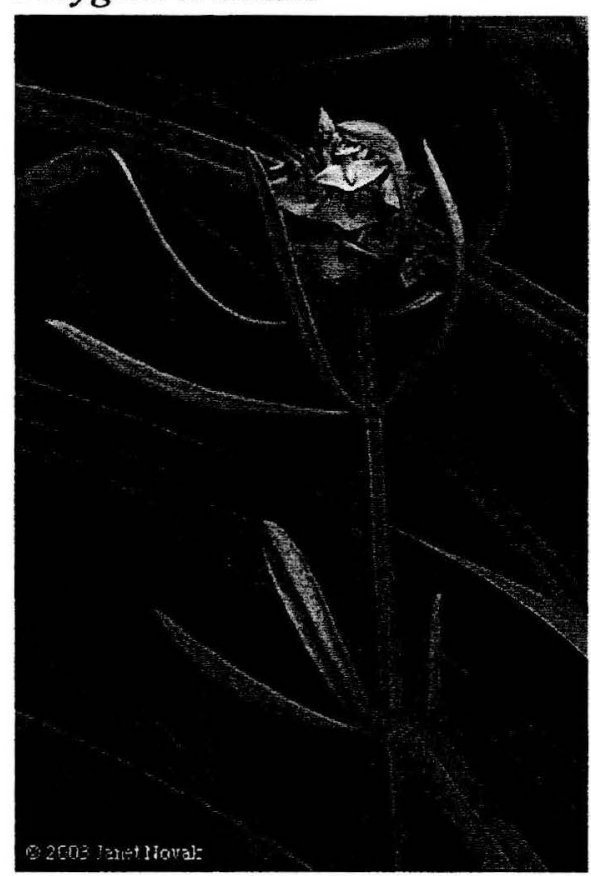

Aletris farinosa
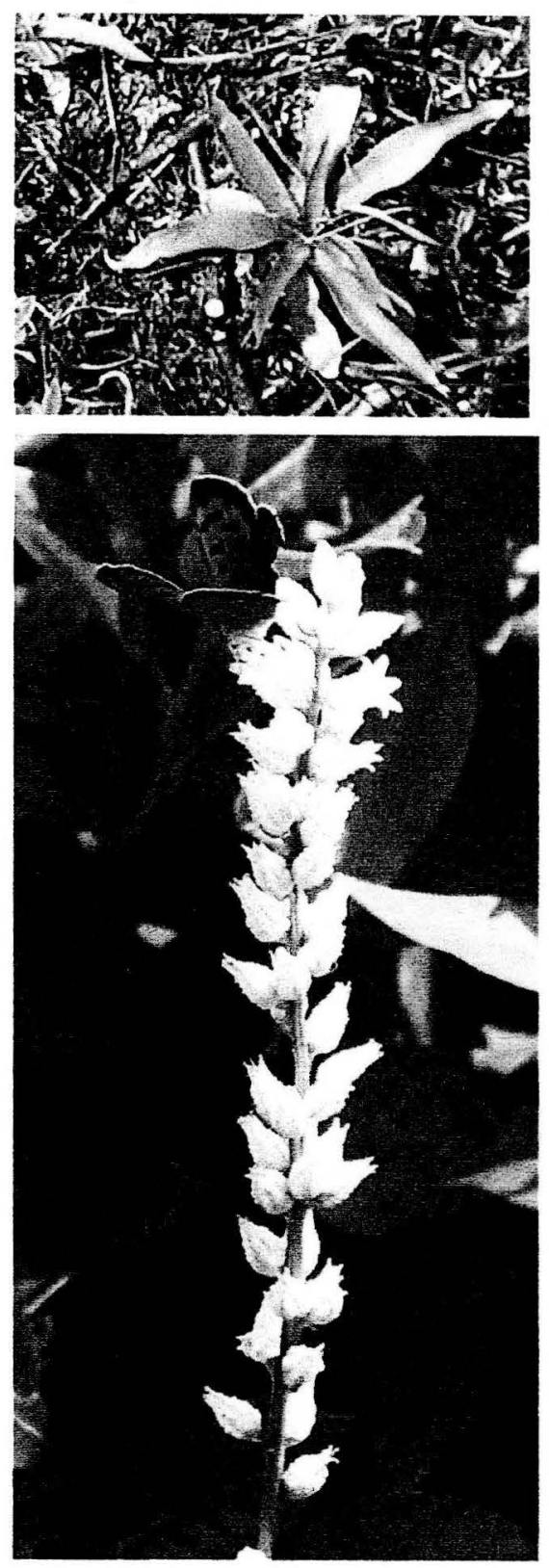

Figure 3: Images of Aletris farinosa, Platanthera ciliaris, and Polygala cruciata. Images of Aletris and Platanthera were taken at the Ninigret site. 

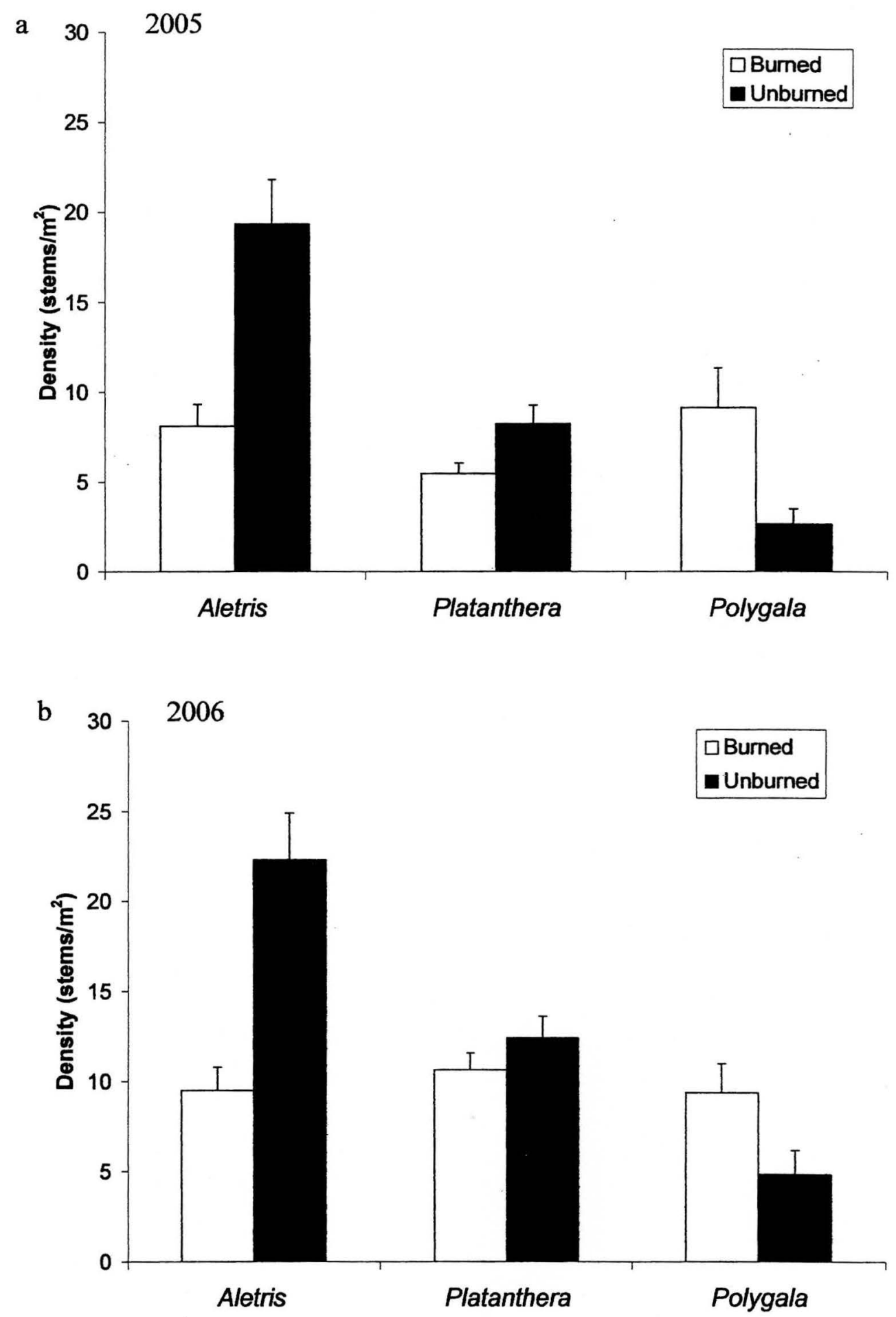

Figure 4: Mean densities for the three rare plant species found in greatest abundance within the NESA core in 2005 (a) and 2006 (b). White bars show mean densities of Aletris, Platanthera, and Polygala for plots that were burned in 2005 and black bars show mean densities for plots not burned in 2005. Pairwise comparisons did not show significant differences $(\mathrm{P}>0.05$, Wilcoxon Rank Sum Test). Error bars indicate standard error of the mean. 

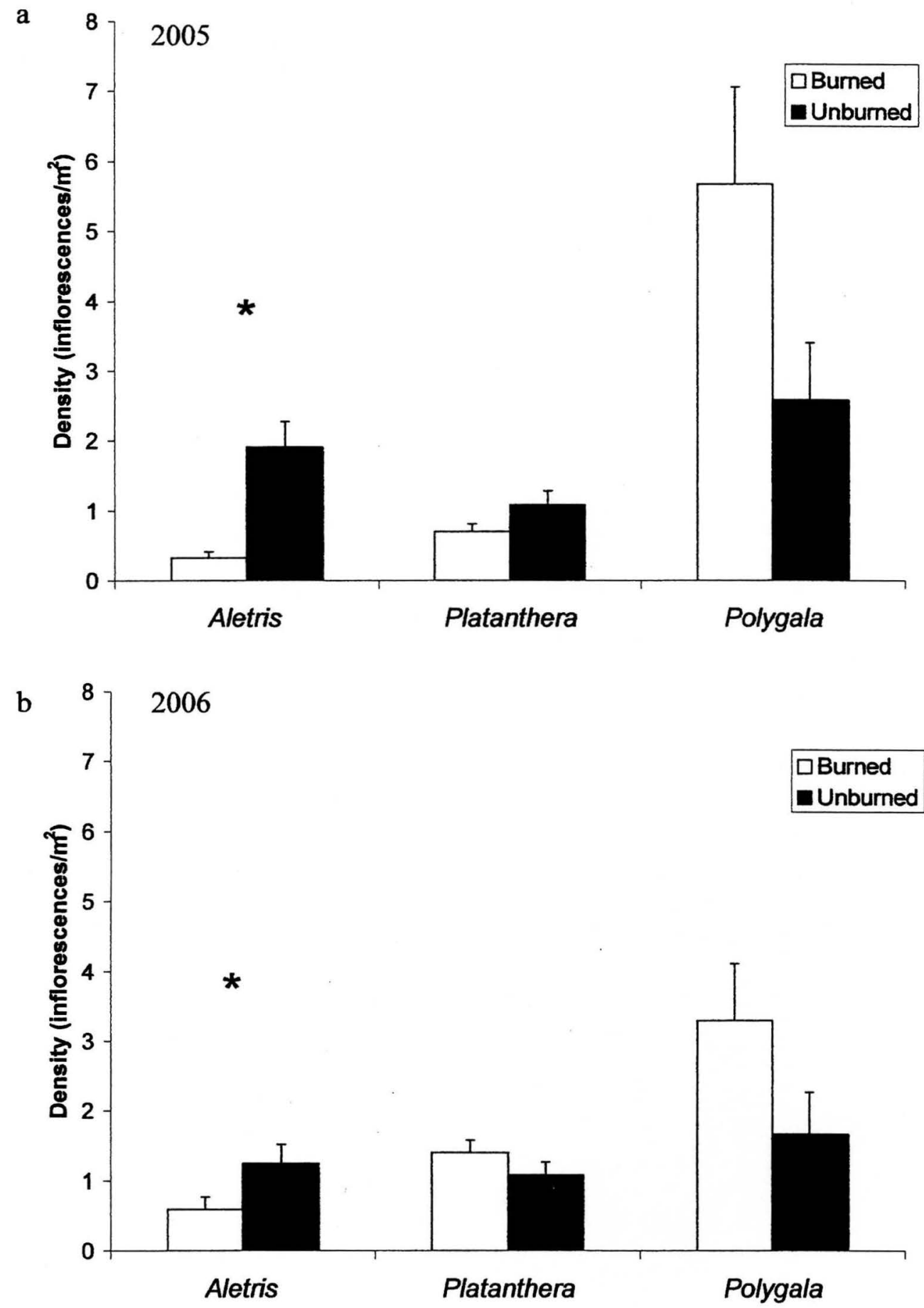

Figure 5: Mean densities of inflorescences for the three rare plant species found in greatest abundance within the NESA core in 2005 (a) and 2006 (b). White bars show mean densities of Aletris, Platanthera, and Polygala inflorescences for plots that were burned in 2005 and black bars show mean densities for plots not burned in 2005 . Asterisks indicate significant differences in pairwise comparisons $(* \mathrm{P}<0.05$, Wilcoxon Rank Sum Test). Error bars indicate standard error of the mean. 

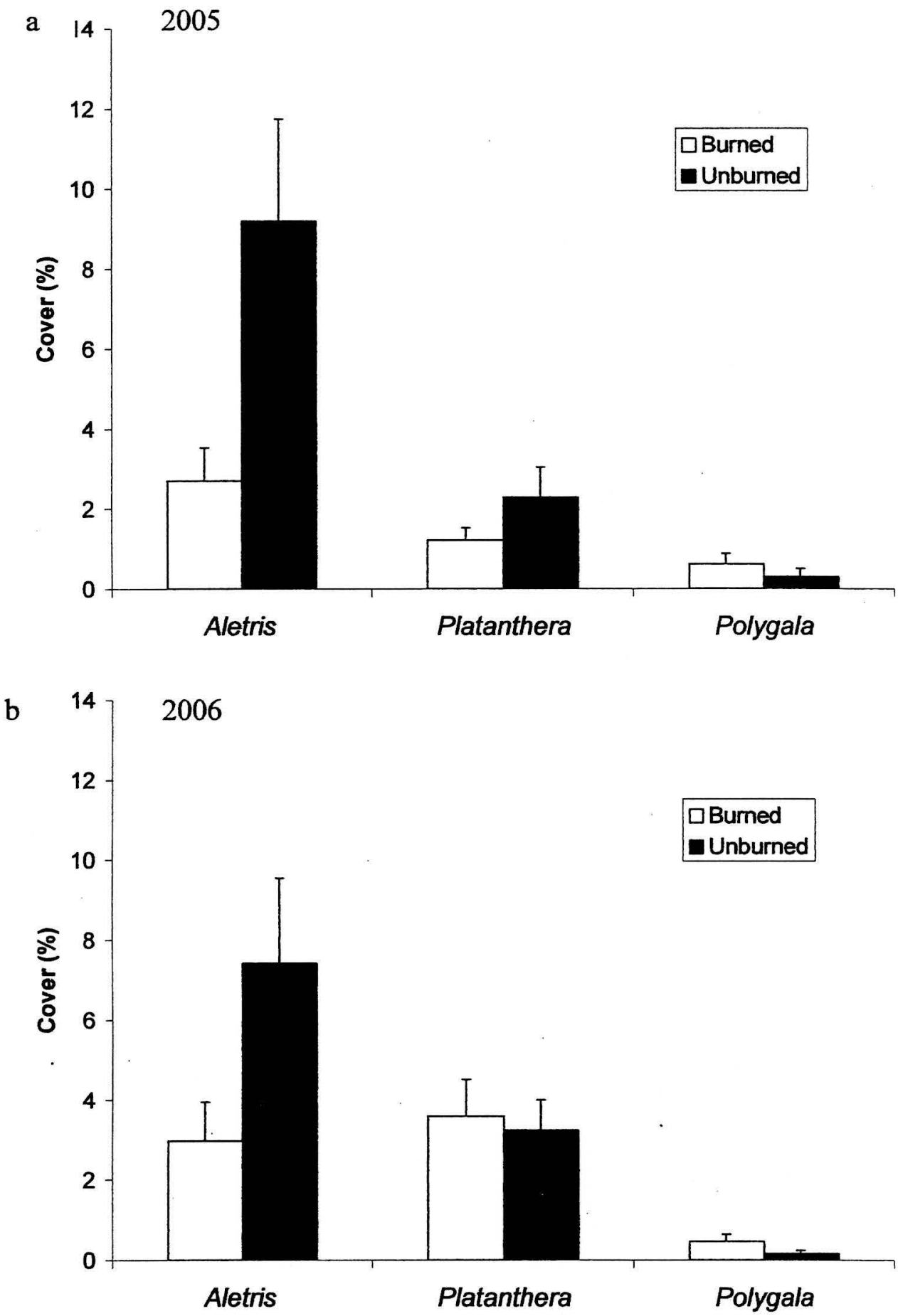

Figure 6: Mean percent cover for the three rare plant species found in greatest abundance within the NESA core in 2005 (a) and 2006 (b). White bars show mean percent cover of Aletris, Platanthera, and Polygala for plots that were burned in 2005 and black bars show mean densities for plots not burned in 2005. Pairwise comparisons did not show significant differences $(\mathrm{P}>0.05$, Wilcoxon Rank Sum Test). Error bars indicate standard error of the mean. 
a

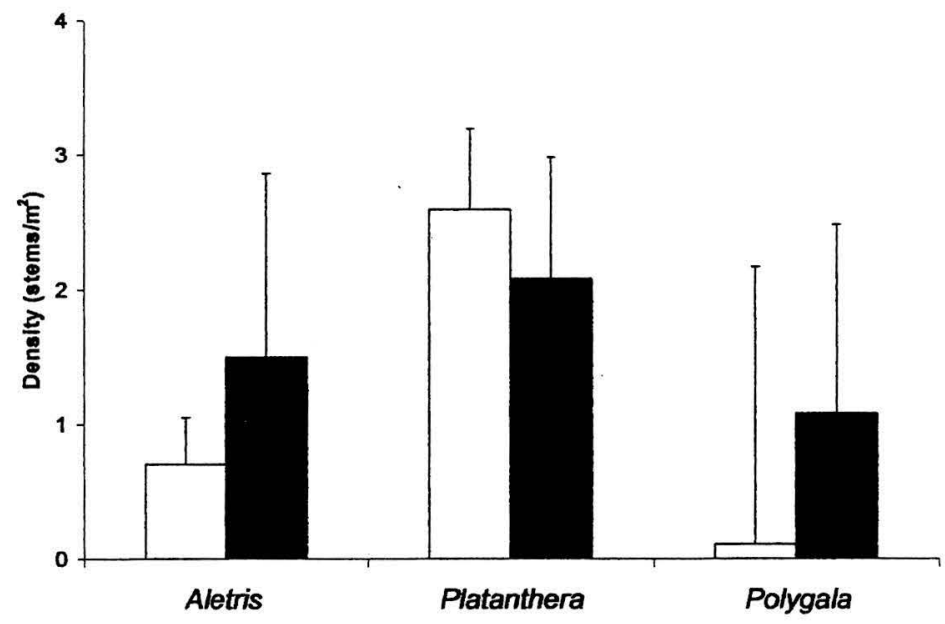

b

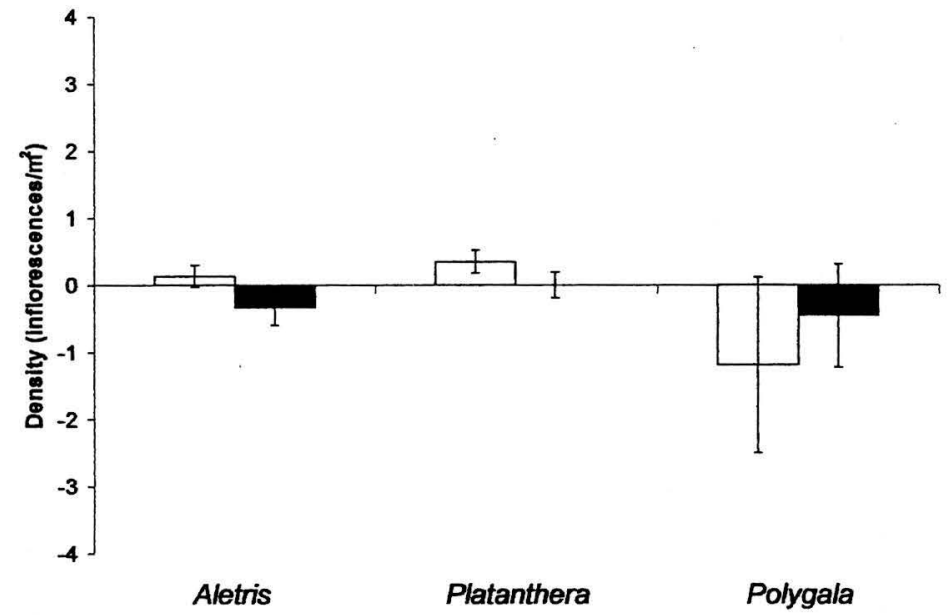

c

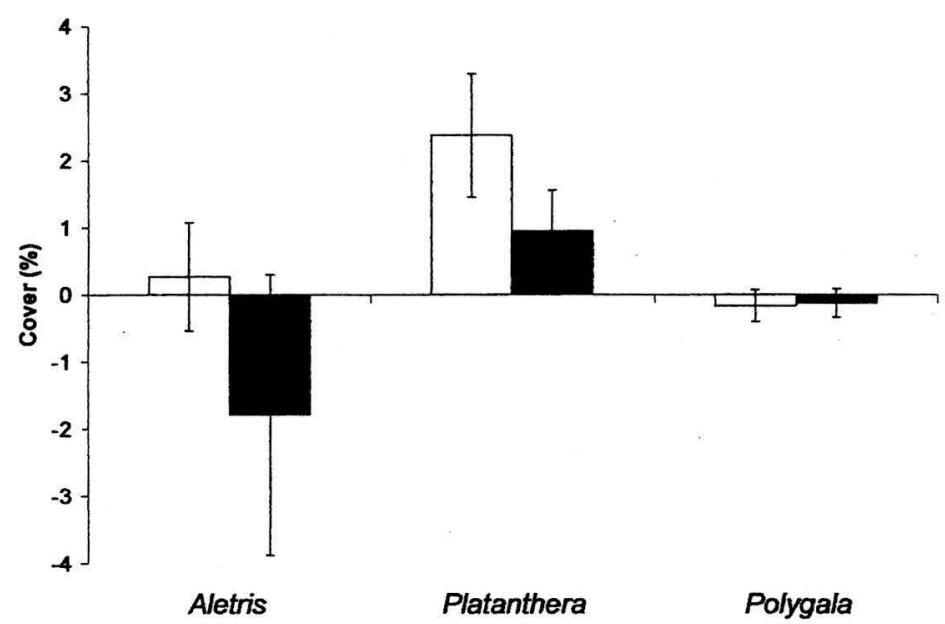

Figure 7: Mean change between 2005 and 2006 in the density of stems (a), inflorescences (b), and percent cover (c), for Aletris, Platanthera, and Polygala in burned plots (white bars) and unburned plots (black bars). Positive values indicate an increase between years and negative values indicate a decrease. Error bars show standard error of the mean. 
a

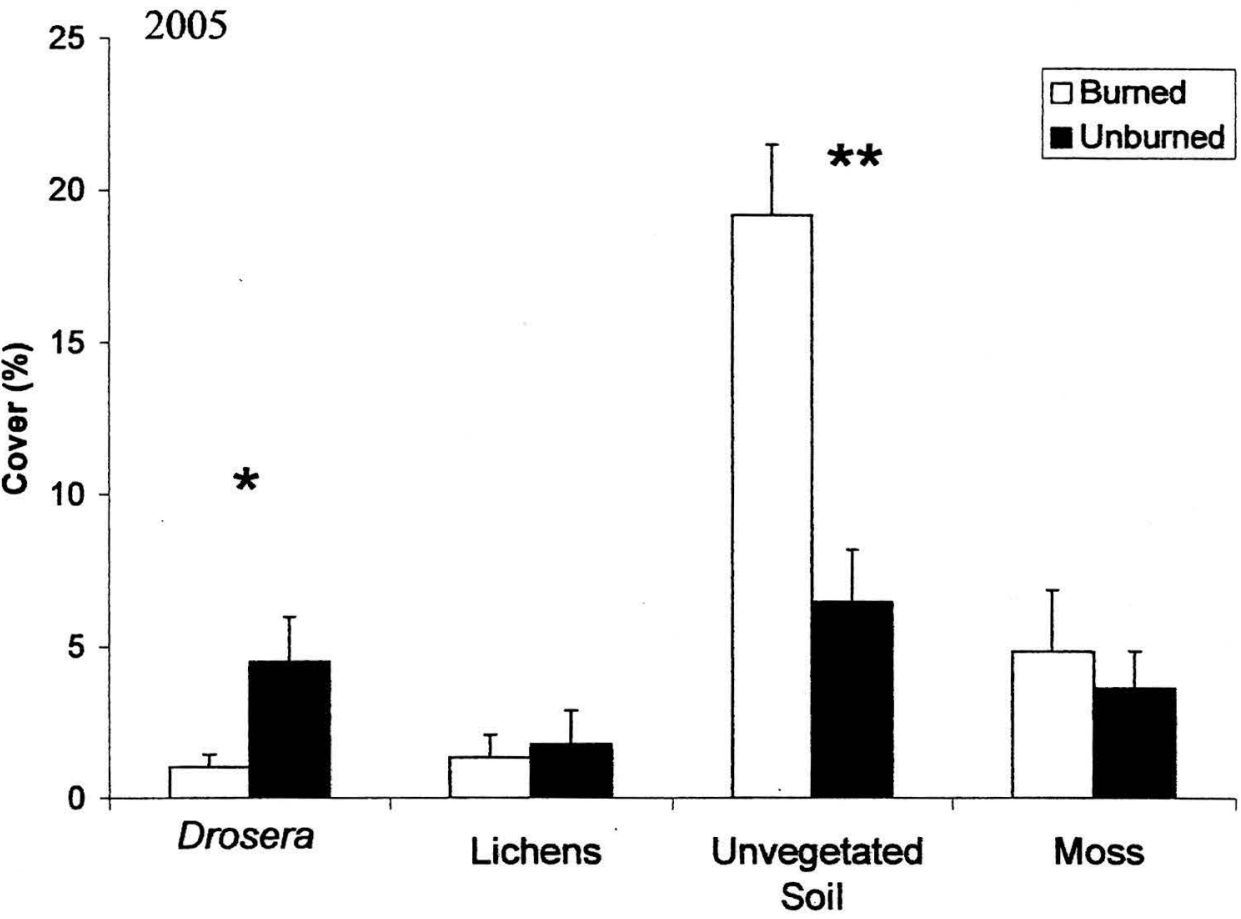

b

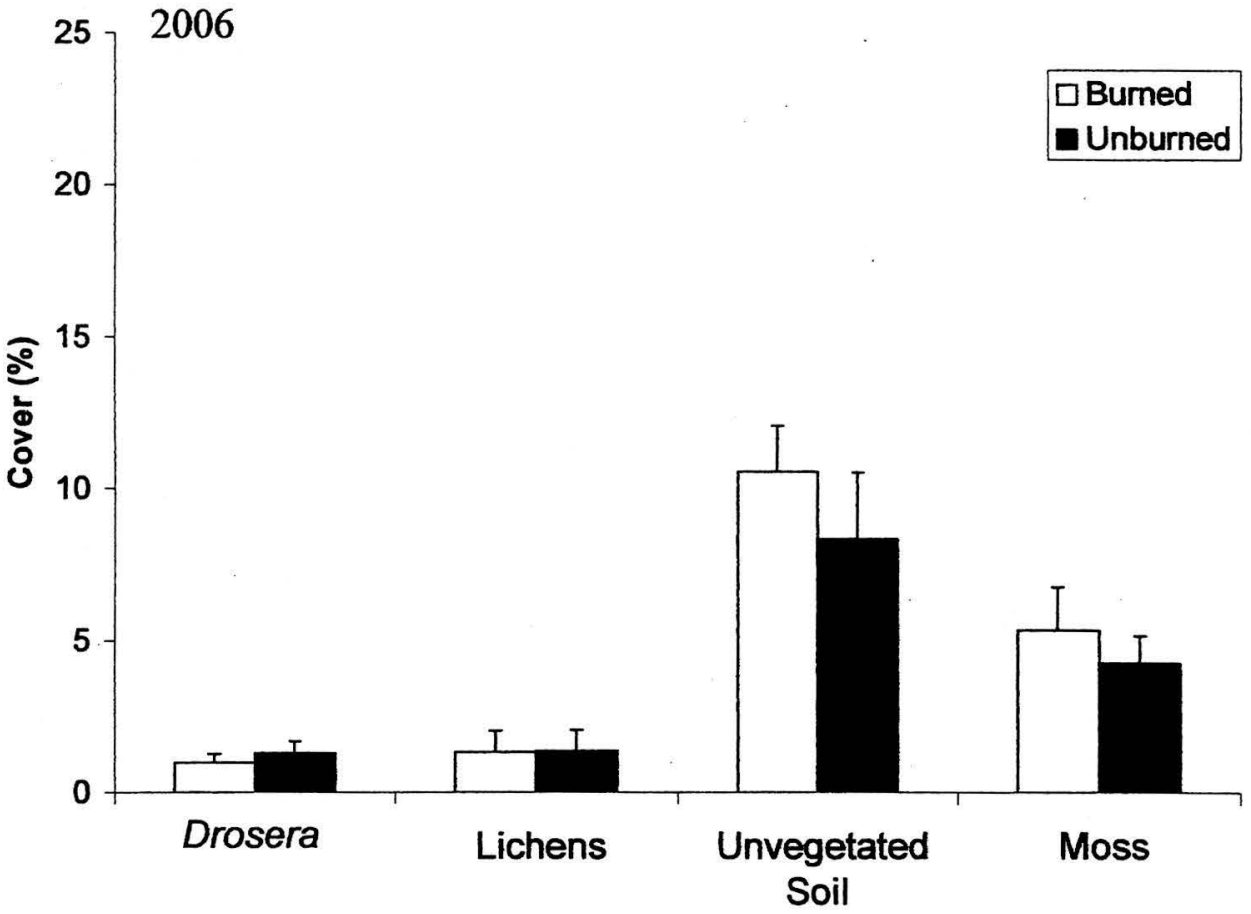

Figure 8: Mean percent cover of Drosera, lichens, unvegetated soil, and moss within the NESA core in 2005 (a) and 2006 (b). White bars show mean percent cover in plots that were burned in 2005 and black bars show mean percent cover for plots not burned in 2005 . Asterisks indicate significant differences in pair-wise comparisons (* $^{*}$ $\mathrm{P}<0.05,{ }^{* *} \mathrm{P}<0.01$, Wilcoxon Rank Sum Test). Error bars indicate standard error of the mean. 
a

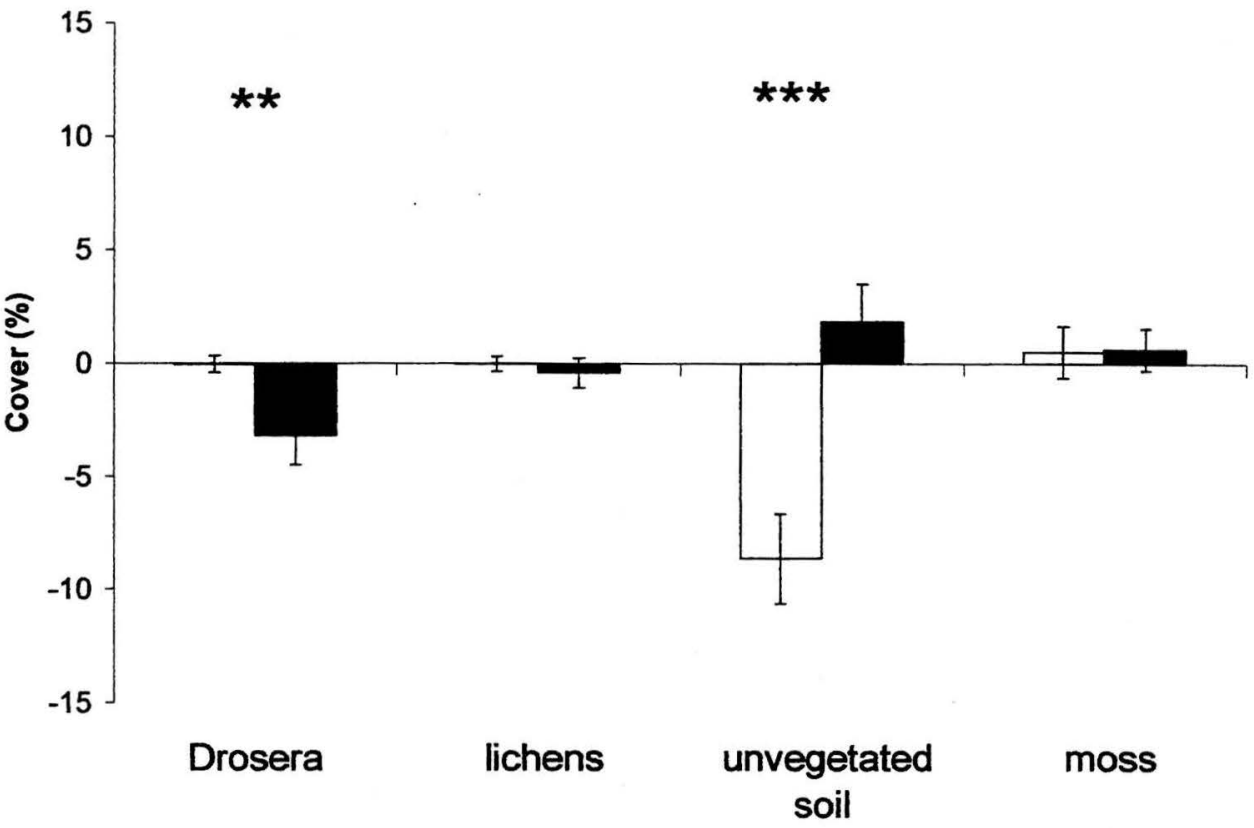

b

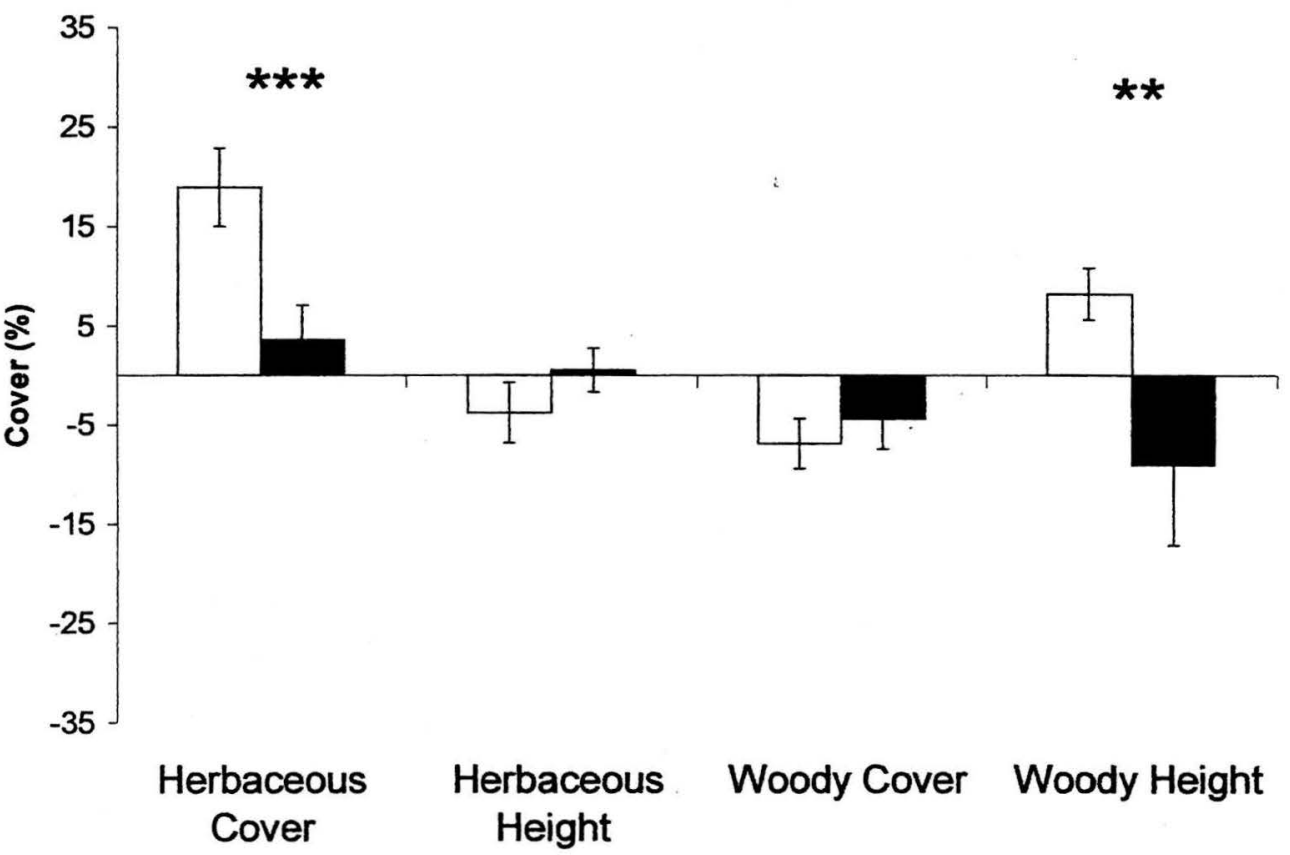

Figure 9: Mean change between 2005 and 2006 in percent cover of Drosera, lichens, unvegetated soil, and moss (a) and herbaceous and woody cover and height (b) for burned plots (white bars) and unburned plots (black bars). Positive values indicate an increase between years and negative values indicate a decrease. Significant differences between the change in burned and unburned plots are indicated with asterisks ( ${ }^{* *} \mathrm{P}<0.01,{ }^{* * *} \mathrm{P}<0.001$, Wilcoxon Rank Sum Test). Error bars show standard error of the mean. 
$\mathbf{a}$
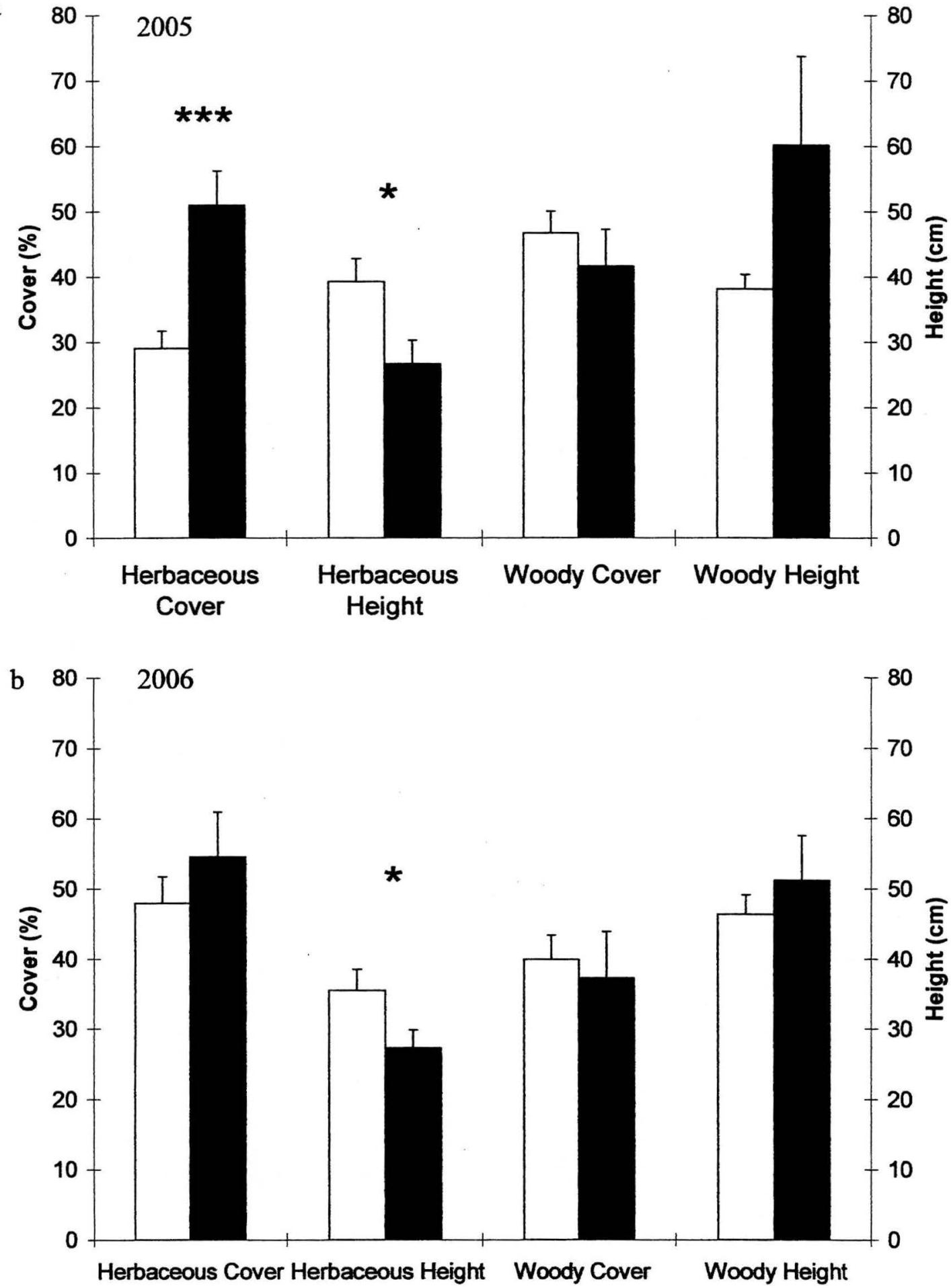

Figure 10: Mean cover and height of herbaceous and woody vegetation within the NESA core in 2005 (a) and 2006 (b). White bars show mean values in plots that were burned in 2005 and black bars show mean values for plots not burned in 2005 .

Asterisks indicate significant differences in pairwise comparisons (*** $\mathrm{P}<0.001$, * $\mathrm{P}<0.05$, Wilcoxon Rank Sum Test). Error bars show standard error of the mean. 

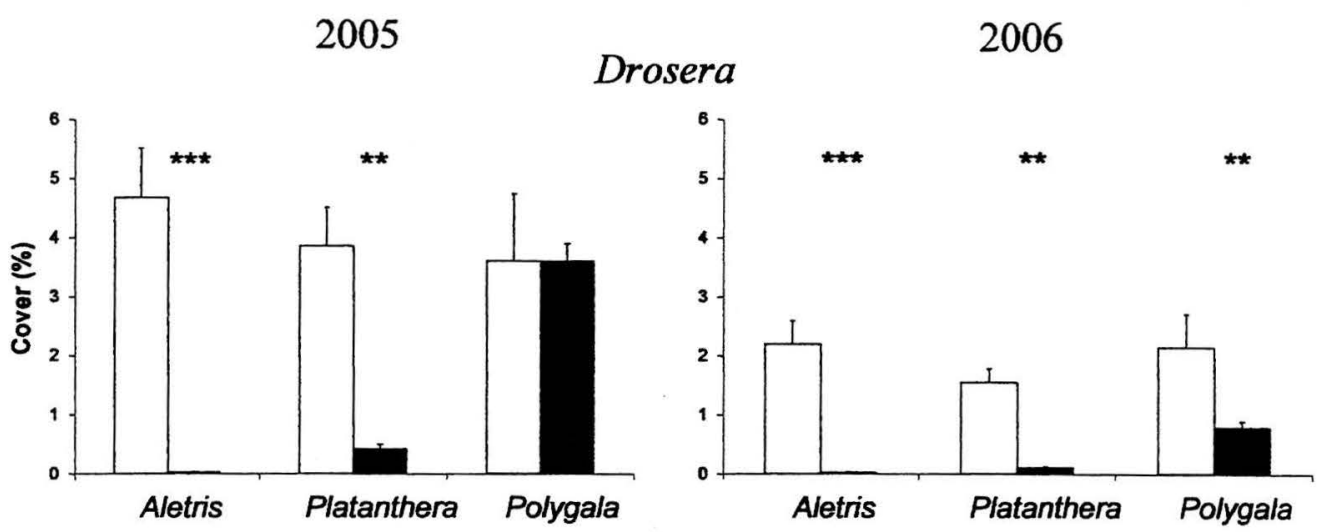

Lichens
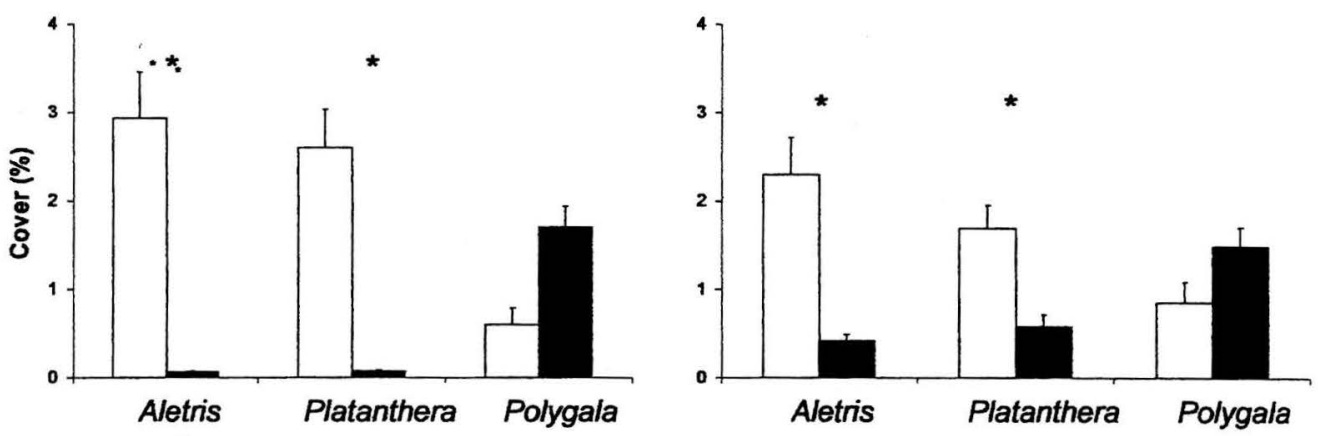

Moss
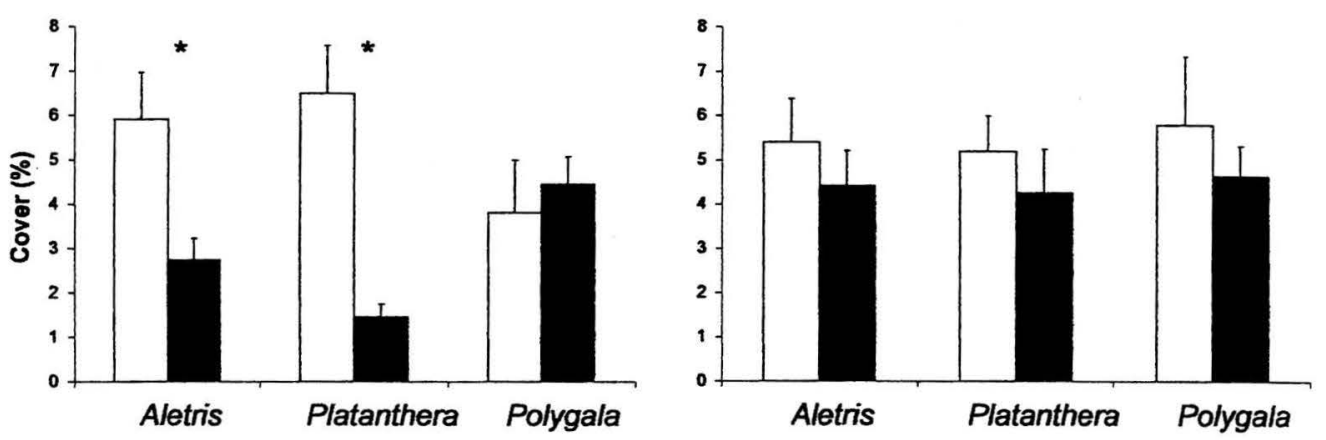

Unvegetated Soil
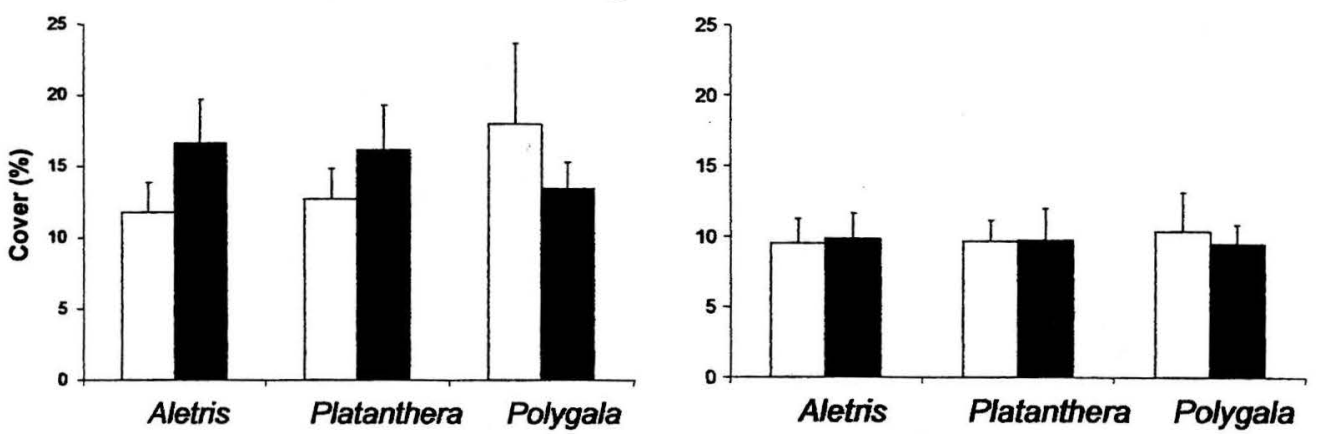

Figure 11: Mean percent cover of Drosera, lichens, moss, and unvegetated soil in the NESA core in 2005 and 2006 for plots in which Aletris, Platanthera and Poylgala were present (white bars) or absent (black bars). Asterisks indicate differences ( ${ }^{* * *} \mathrm{P}<0.001 ;{ }^{* *} \mathrm{P}<0.01$; ${ }^{*} \mathrm{P}<0.05$, Wilcoxon Rank Sum Test). 

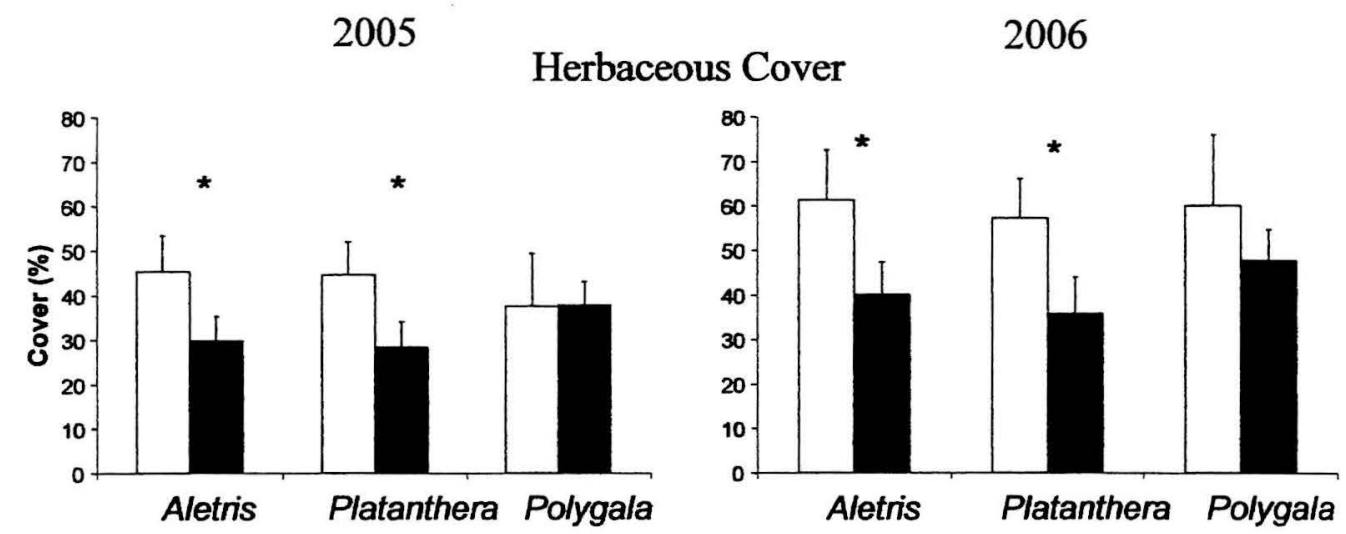

Herbaceous Mean Height
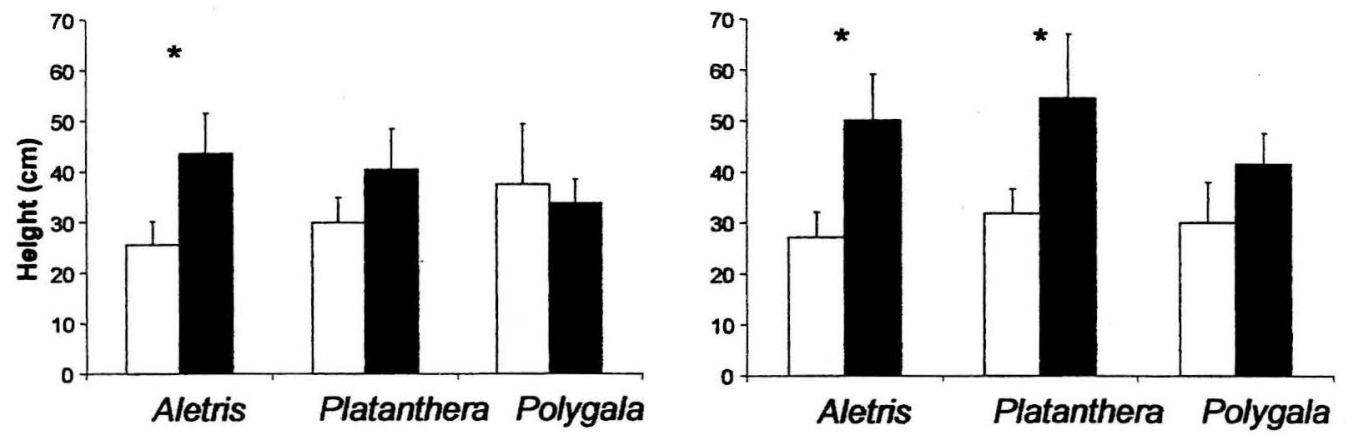

Woody Cover
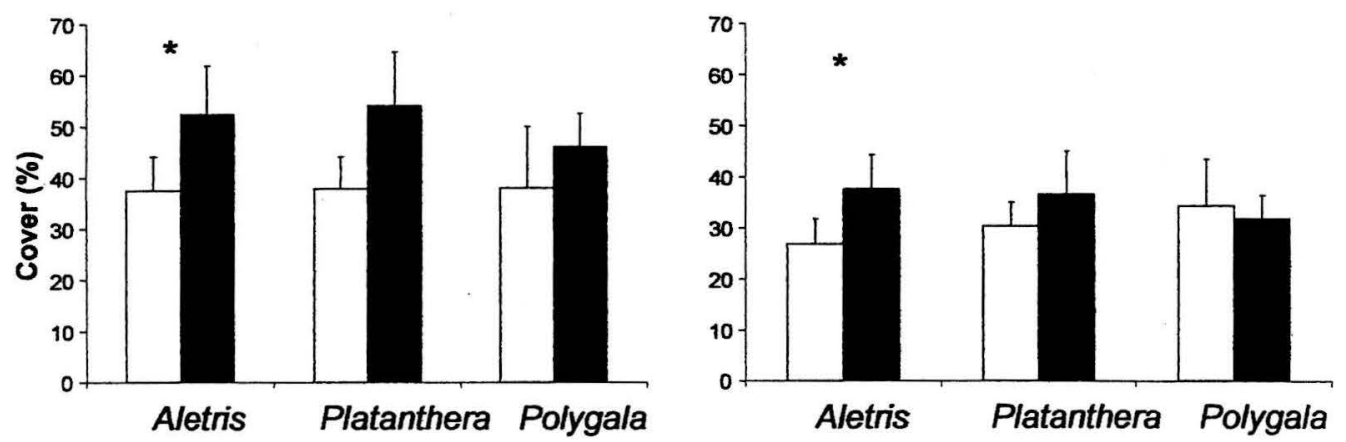

Woody Mean Height
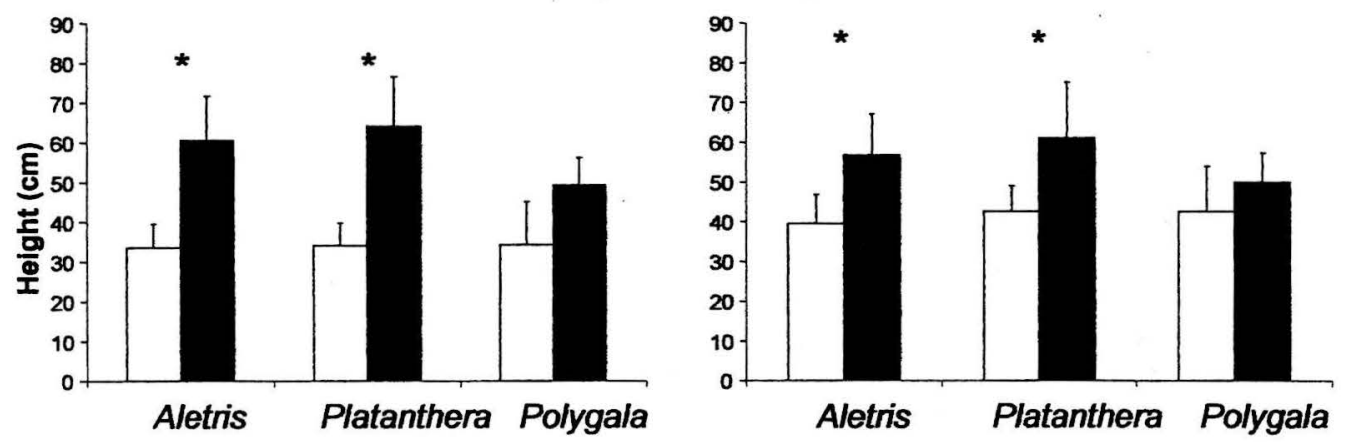

Figure 12: Mean percent cover and height of herbaceous and woody vegetation in the NESA core in 2005 and 2006 for plots in which Aletris, Platanthera and Poylgala were present (white bars) or absent (black bars). Asterisks indicate differences ( ${ }^{* * *} \mathrm{P}<0.001 ;{ }^{* *} \mathrm{P}<0.01 ;{ }^{*} \mathrm{P}<0.05$, Wilcoxon Rank Sum Test). 
a

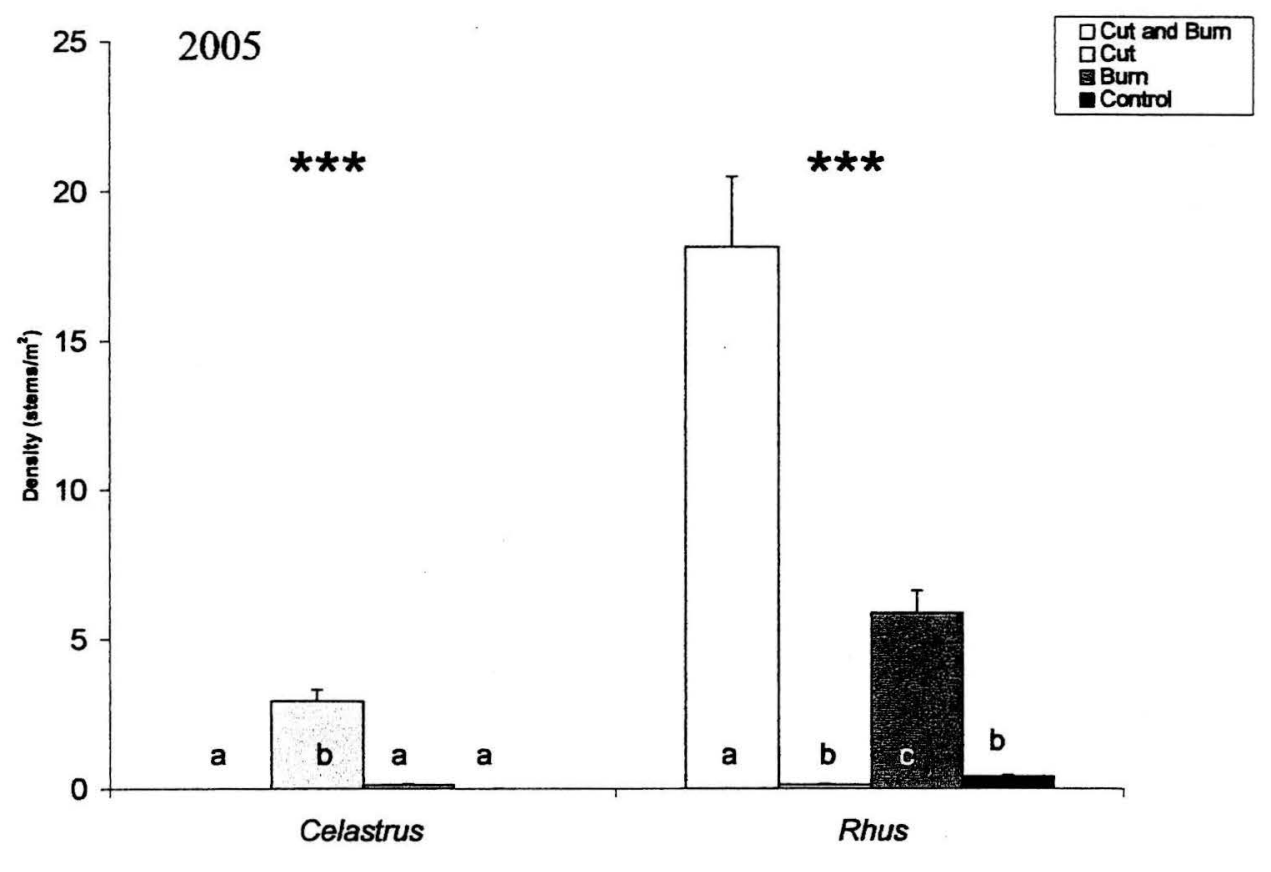

b

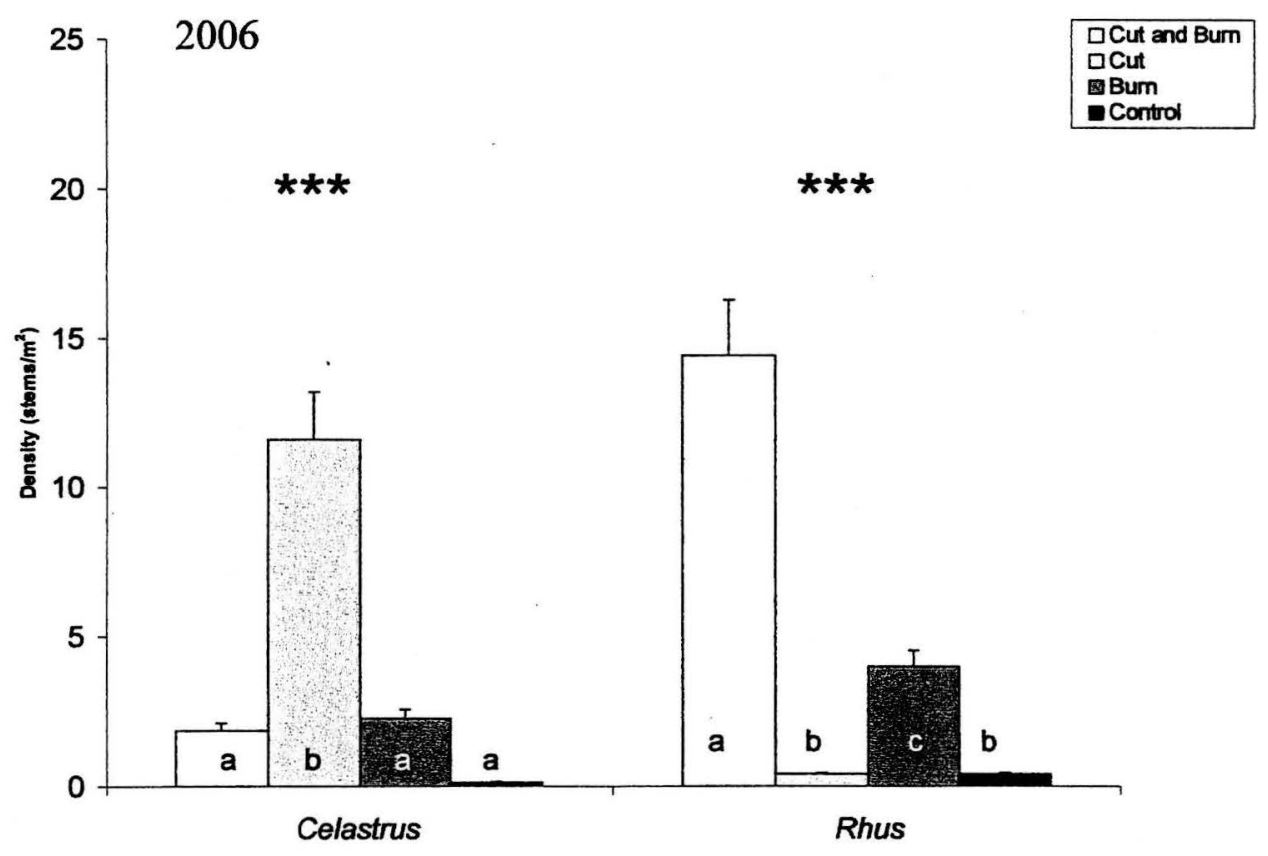

Figure 13: Mean densities of Celastrus and Rhus in the experimental treatment sectors adjacent to the NESA core. Bars show mean values for the cut and burn sector, the cut sector, the burn sector, and the control sector for both 2005 (a) and 2006 (b) data. Different letters indicate significant differences $(P<0.05$, Wilcoxon Rank Sum Test) in pairwise comparisons, while asterisks indicate significant differences in groupwise comparisons $\left({ }^{* * *} \mathrm{P}<0.001 ;{ }^{* *} \mathrm{P}<0.01 ;{ }^{*} \mathrm{P}<0.05\right.$, Kruskal-Wallis Test). Error bars show standard errors of the mean. 
a

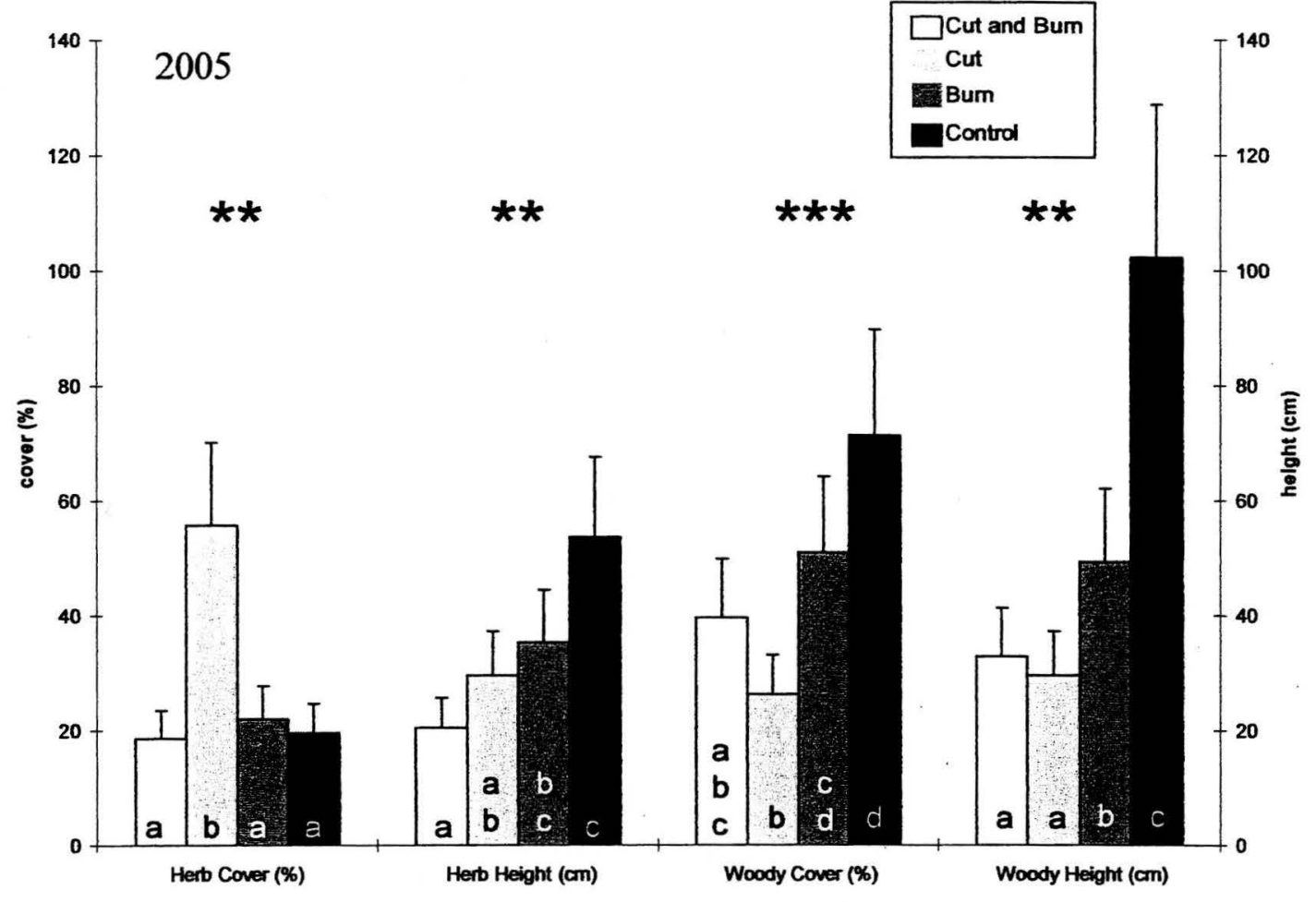

b

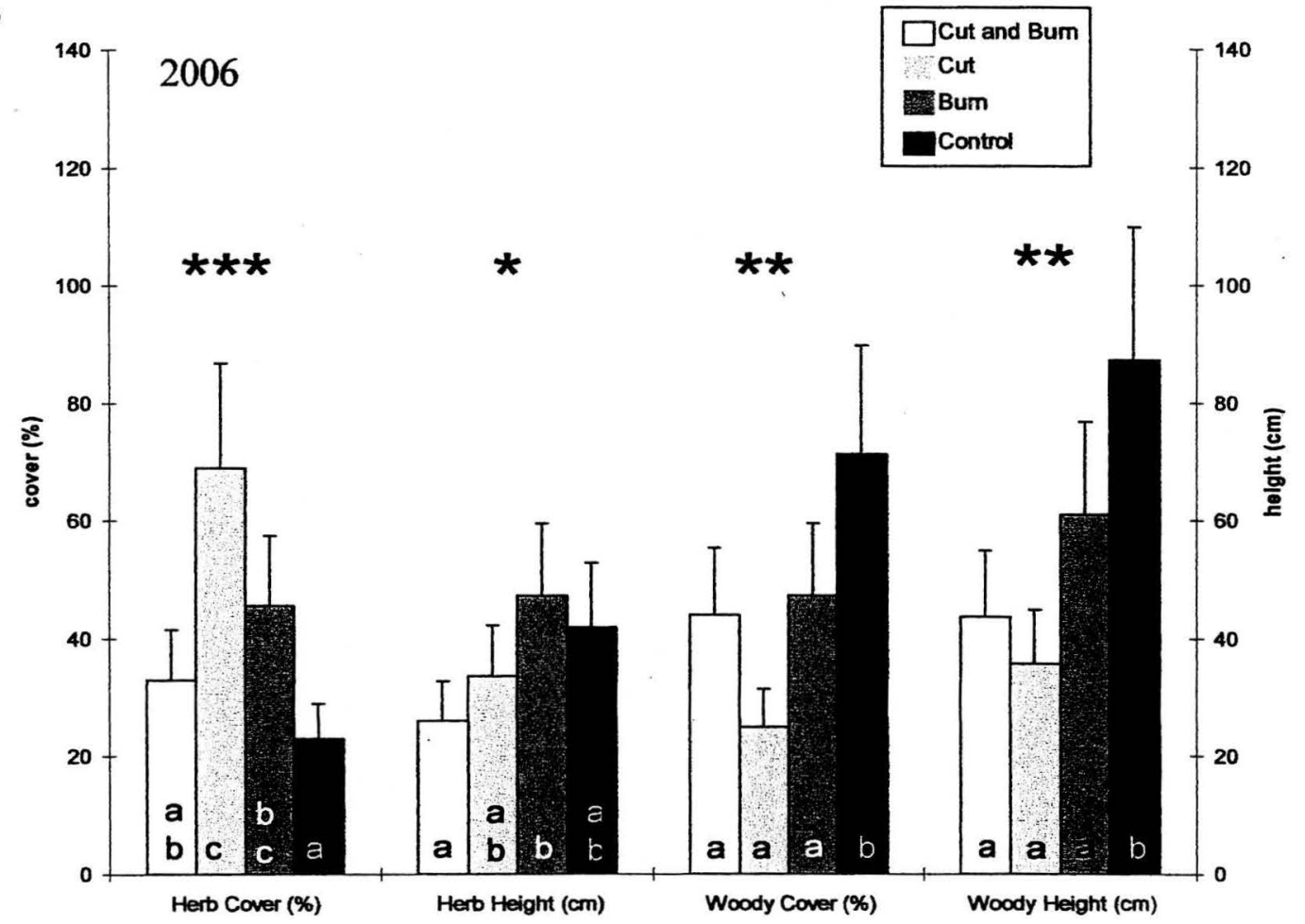

Figure 14: Mean cover and height of herbaceous and woody vegetation in experimental treatment sectors adjacent to the NESA core. Bars show mean values for the cut and burn sector, the cut sector, the burn sector, and the control sector for both 2005 (a) and 2006 (b) data. Different letters indicate significant differences $(P<0.05$, Wilcoxon Rank Sum Test) in pairwise comparisons, while asterisks indicate significant differences in groupwise comparisons $\left(* * * \mathrm{P}<0.001 ;{ }^{* * P}<0.01 ;{ }^{*} \mathrm{P}<0.05\right.$, Kruskal-Wallis Test). Error bars show standard errors of the mean. 
Appendix A

Charring Classes and Max Temps for unburned plots in the NESA core (2005)

Plot \# Charring Class Max Temp ( $\left.{ }^{\circ} \mathrm{F}\right)$

$1 \mathrm{~A}$

$2 \mathrm{~A}$

$3 \mathrm{~A}$

$4 \mathrm{~A}$

$5 \mathrm{~A}$

$9 \mathrm{~B}$

$13 \mathrm{~A}$

$14 \mathrm{~A}$

$18 \mathrm{~B}$

$21 \mathrm{~A}$

$22 \mathrm{~A}$

$31 \mathrm{~A}$

$32 \mathrm{~A}$

$34 \mathrm{~A}$

$35 \mathrm{~A}$

$39 \mathrm{~A}$

$45 \mathrm{~A}$

$46 \mathrm{~A}$

$48 \mathrm{~B}$

$49 \mathrm{~B}$

$53 \mathrm{~A}$

$54 \mathrm{~A}$

$56 \mathrm{~A}$

$61 \mathrm{~B}$
0

0

0

0

0

0

0

0

0

0

0

0

0

0

0

0

0

0

0

0

0

0
Charring Classes and Max Temps for burned plots located in the NESA core (2005)

Plot \# Charring Class Max Temp ( $\left.{ }^{\circ} \mathrm{F}\right)$

$6 \mathrm{G}$

$7 \mathrm{G}$

$8 \mathrm{G} \quad 400$

$10 \mathrm{C}$

$11 \mathrm{E}$

$12 \mathrm{E}$

$15 \mathrm{G}$

$16 \mathrm{G}$

$17 \mathrm{G}$

$19 \mathrm{E}$

$20 \mathrm{~B}$

$23 \mathrm{G}$

$24 \mathrm{~F}$

$25 \mathrm{~F}$

$26 \mathrm{E}$

$27 \mathrm{G}$

$28 \mathrm{E}$

$29 \mathrm{~F}$

$30 \mathrm{G}$

$33 \mathrm{G}$

$36 \mathrm{G}$

$37 \mathrm{G}$

$38 \mathrm{G}$

$40 \mathrm{G}$

$41 \mathrm{G}$

$42 \mathrm{G}$

$43 \mathrm{G}$

$44 \mathrm{E}$

$47 \mathrm{G}$

$50 \mathrm{E}$

$51 \mathrm{G}$

$52 \mathrm{G}$

$55 \mathrm{G}$

$57 \mathrm{G}$

$58 \mathrm{G}$

$59 \mathrm{G}$

$60 \mathrm{~F}$
400

0

0

800

400

800

0

200

400

0

0

0

1000

0

0

800

200

600

200

0

200

200

400

400

200

600

0

800

200

400

800

800

800

400 


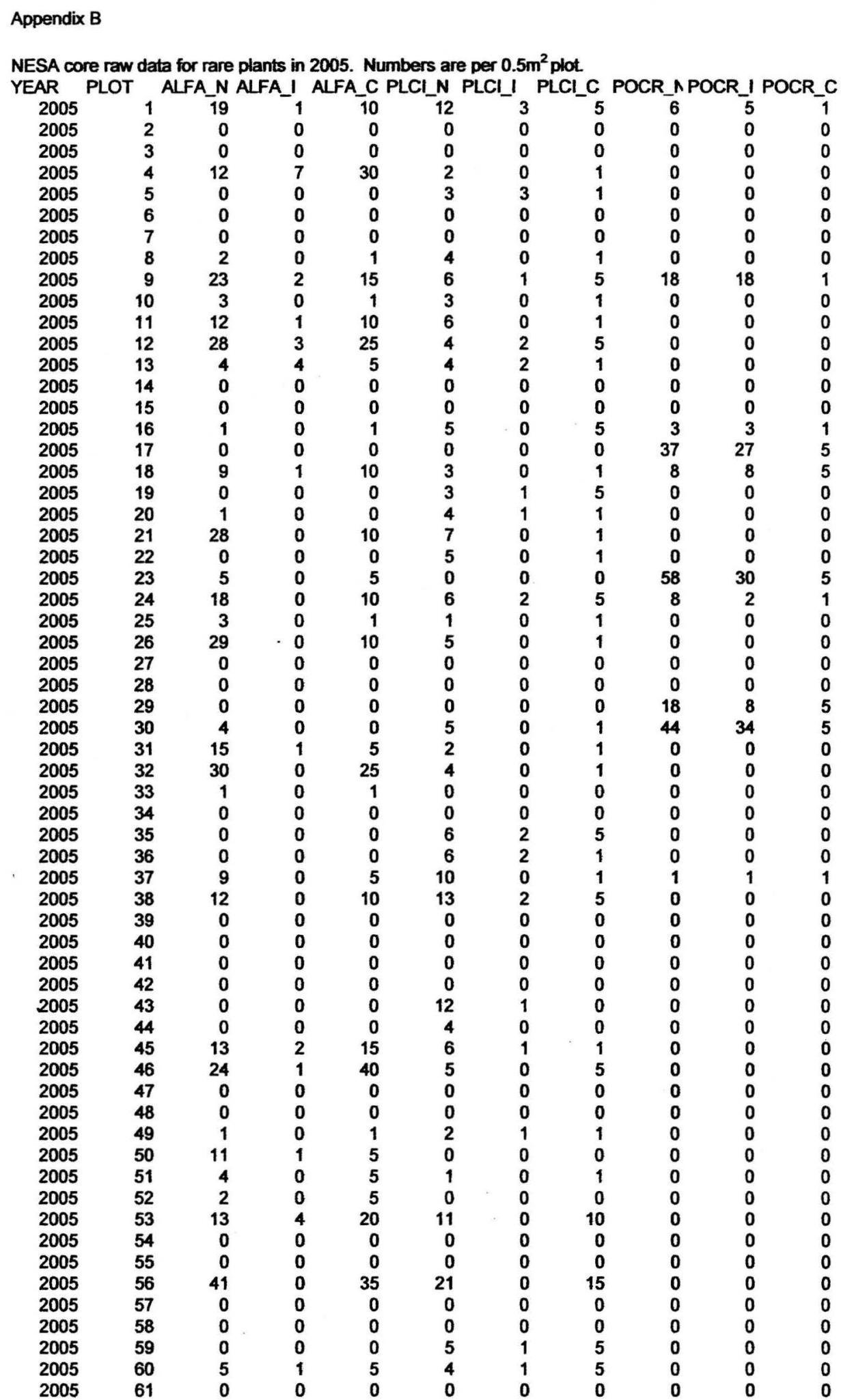

ALFA = Aletris farinosa stems $/ 0.5 \mathrm{~m}^{2}$ plot $(\mathrm{N})$, inflorescences $/ 0.5 \mathrm{~m}^{2}$ plot $(\mathrm{l})$, and percent cover $/ 0.5 \mathrm{~m}^{2}$ plot $(\mathrm{C})$ $\mathrm{PLCl}=$ Platanthera ciliaris stems $/ 0.5 \mathrm{~m}^{2}$ plot $(\mathrm{N})$, inflorescences $/ 0.5 \mathrm{~m}^{2}$ plot $(\mathrm{I})$, and percent cover $10.5 \mathrm{~m}^{2}$ plot ( C) $P O C R=$ Polygala cruciata stems $/ 0.5 \mathrm{~m}^{2}$ plot $(\mathrm{N})$, inflorescences $/ 0.5 \mathrm{~m}^{2}$ plot $(\mathrm{I})$, and percent cover $/ 0.5 \mathrm{~m}^{2}$ plot $(\mathrm{C})$ 
NESA core raw data for rare plants in 2006

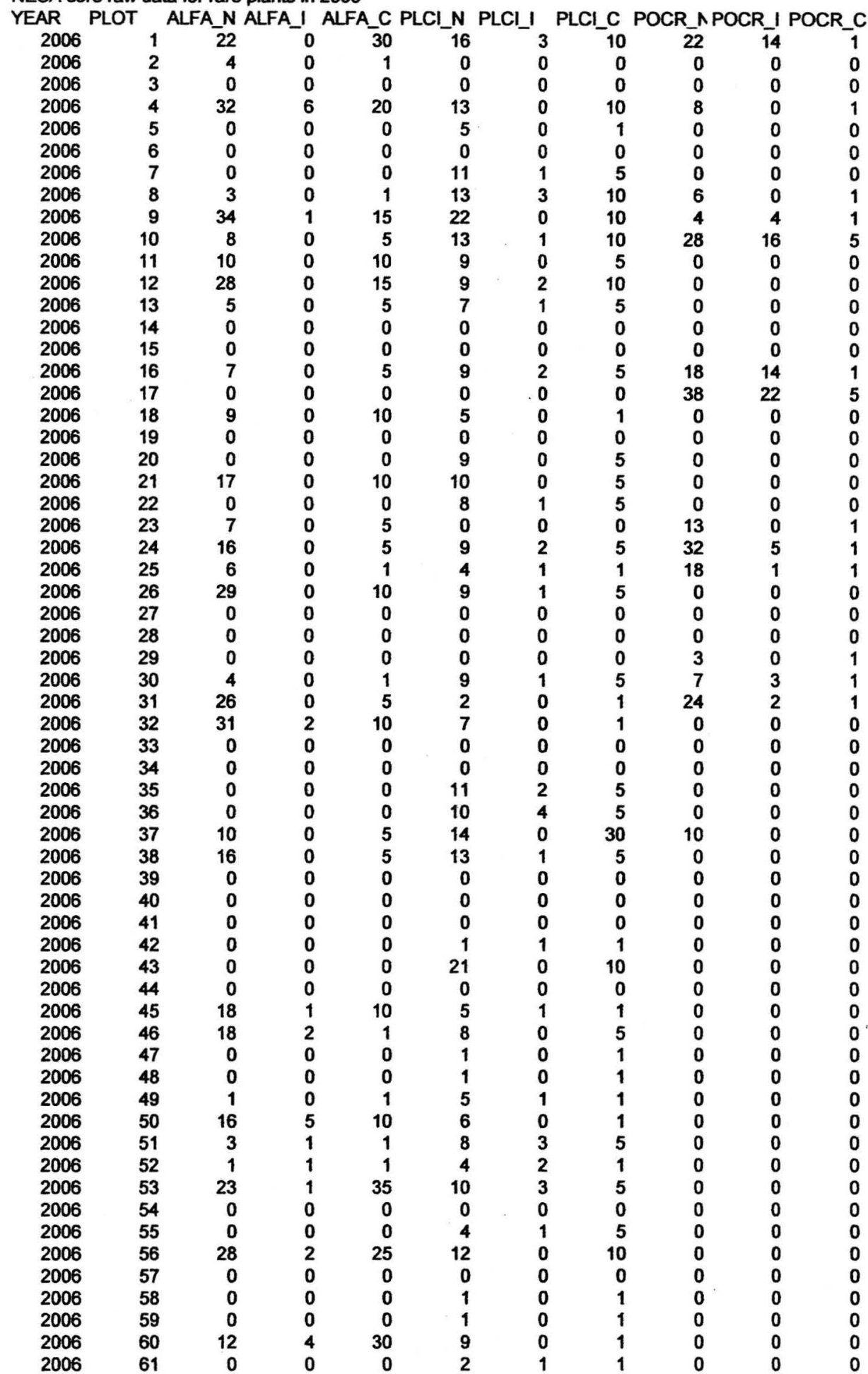

ALFA = Aletris farinosa stems $/ 0.5 \mathrm{~m}^{2}$ plot $(\mathrm{N})$, inflorescences $/ 0.5 \mathrm{~m}^{2}$ plot (I), and percent cover $10.5 \mathrm{~m}^{2}$ plot ( C) $\mathrm{PLCl}=$ Platanthera ciliaris stems $/ 0.5 \mathrm{~m}^{2}$ plot $(\mathrm{N})$, infiorescences $/ 0.5 \mathrm{~m}^{2}$ plot (I), and percent cover $/ 0.5 \mathrm{~m}^{2}$ plot (C) POCR = Polygala cruciata stems $/ 0.5 \mathrm{~m}^{2}$ plot $(\mathrm{N})$, inflorescences $/ 0.5 \mathrm{~m}^{2}$ plot $(\mathrm{I})$, and percent cover $/ 0.5 \mathrm{~m}^{2}$ plot (C) 


\begin{tabular}{|c|c|c|c|c|c|c|c|c|c|c|}
\hline NESA CO & re raw date & ta for all oth & her plants ar & Ind variable & es in 2005 & & & & & \\
\hline YEAR & PLOT & DROS_N & DROS_C & UCH_C I & UNVG_C & MOSS_C & HERB_C & HERB_H & WOOD_C & WOOD_H \\
\hline 2005 & 1 & 45 & 5 & 0 & -5 & 0 & 55 & 20 & 40 & 48 \\
\hline 2005 & 2 & 0 & 0 & 0 & 0 & 0 & 15 & 35 & 85 & 60 \\
\hline 2005 & 3 & 0 & 0 & 0 & 5 & 0 & 55 & 30 & 40 & 45 \\
\hline 2005 & 4 & 0 & 0 & 10 & 0 & 10 & 70 & 15 & 30 & 30 \\
\hline 2005 & 5 & 30 & 1 & 0 & 0 & 5 & 75 & 20 & 25 & 30 \\
\hline 2005 & 6 & 0 & 0 & 0 & 40 & 0 & 50 & 65 & 10 & 45 \\
\hline 2005 & 7 & 0 & 0 & 0 & 50 & 0 & 40 & 50 & 10 & 45 \\
\hline 2005 & 8 & 0 & 0 & 0 & 30 & 0 & 40 & 20 & 30 & 38 \\
\hline 2005 & 9 & 52 & 5 & 0 & 5 & 5 & 70 & 20 & 20 & 50 \\
\hline 2005 & 10 & 32 & 1 & 0 & 0 & 5 & 25 & 10 & 75 & 30 \\
\hline 2005 & 11 & 0 & 0 & 10 & 10 & 5 & 30 & 20 & 35 & 35 \\
\hline 2005 & 12 & 4 & 1 & 25 & 10 & 5 & 60 & 10 & 15 & 30 \\
\hline 2005 & 13 & 2 & 1 & 0 & 0 & 1 & 30 & 15 & 70 & 45 \\
\hline 2005 & 14 & 0 & 0 & 0 & 0 & 0 & 0 & 0 & 100 & 300 \\
\hline 2005 & 15 & 0 & 0 & 0 & 5 & 0 & 25 & 70 & 70 & 40 \\
\hline 2005 & 16 & 0 & 0 & 0 & 10 & 0 & 40 & 50 & 50 & 30 \\
\hline 2005 & 17 & 0 & 0 & 0 & 35 & 0 & 40 & 65 & 25 & 30 \\
\hline 2005 & 18 & 95 & 15 & 0 & 20 & 0 & 50 & 10 & 25 & 20 \\
\hline 2005 & 19 & 0 & 0 & 0 & 10 & 40 & 15 & 35 & 85 & 35 \\
\hline 2005 & 20 & 0 & 0 & 0 & 0 & 60 & 10 & 20 & 85 & 40 \\
\hline 2005 & 21 & 105 & 10 & 25 & 10 & 5 & 70 & 10 & 5 & 18 \\
\hline 2005 & 22 & 0 & 0 & 0 & 25 & 5 & 40 & 65 & 30 & 35 \\
\hline 2005 & 23 & 33 & 1 & 0 & 10 & 0 & 40 & 30 & 50 & 30 \\
\hline 2005 & 24 & 74 & 10 & 5 & 15 & 1 & 30 & 20 & 40 & 30 \\
\hline 2005 & 25 & 49 & 5 & 1 & 20 & 1 & 10 & 20 & 70 & 25 \\
\hline 2005 & 26 & 85 & 5 & 5 & 10 & 15 & 30 & 20 & 40 & 35 \\
\hline 2005 & 27 & 0 & 0 & 0 & 50 & 0 & 15 & 90 & 35 & 25 \\
\hline 2005 & 28 & 0 & 0 & 0 & 0 & 0 & 50 & 30 & 50 & 40 \\
\hline 2005 & 29 & 0 & 0 & 0 & 20 & 30 & 20 & 50 & 30 & 25 \\
\hline 2005 & 30 & 0 & 0 & 1 & 50 & 1 & 10 & 50 & 40 & 40 \\
\hline 2005 & 31 & 52 & 5 & 5 & 25 & 1 & 50 & 20 & 25 & 25 \\
\hline 2005 & 32 & 76 & 10 & 0 & 5 & 25 & 80 & 20 & 15 & 35 \\
\hline 2005 & 33 & 0 & 0 & 0 & 25 & 1 & 45 & 65 & 40 & 40 \\
\hline 2005 & 34 & 0 & 0 & 0 & 10 & 0 & 15 & 25 & 85 & 160 \\
\hline 2005 & 35 & 0 & 0 & 0 & 20 & 0 & 40 & 50 & 40 & 35 \\
\hline 2005 & 36 & 0 & 0 & 0 & 20 & 0 & 40 & 60 & 30 & 40 \\
\hline 2005 & 37 & 0 & 0 & 0 & 10 & 1 & 20 & 60 & 60 & 40 \\
\hline 2005 & 38 & 80 & 5 & 1 & 30 & 1 & 30 & 30 & 25 & 20 \\
\hline 2005 & 39 & 0 & 0 & 0 & 0 & 0 & 10 & 12 & 90 & 200 \\
\hline 2005 & 40 & 0 & 0 & 0 & 20 & 1 & 10 & 70 & 70 & 50 \\
\hline 2005 & 41 & 0 & 0 & 0 & 15 & 0 & 20 & 60 & 65 & 40 \\
\hline 2005 & 42 & 0 & 0 & 0 & 10 & 0 & 30 & 50 & 60 & 45 \\
\hline 2005 & 43 & 0 & 0 & 0 & 25 & 0 & 40 & 70 & 35 & 30 \\
\hline 2005 & 44 & 0 & 0 & 1 & 40 & 0 & 5 & 40 & 50 & 30 \\
\hline 2005 & 45 & 200 & 15 & 0 & 5 & 5 & 65 & 30 & 30 & 50 \\
\hline 2005 & 46 & 38 & 5 & 0 & 0 & 5 & 85 & 25 & 15 & 30 \\
\hline 2005 & 47 & 0 & 0 & 0 & 10 & 1 & 10 & 10 & 70 & 100 \\
\hline 2005 & 48 & 0 & 0 & 1 & 15 & 0 & 20 & 60 & 70 & 50 \\
\hline 2005 & 49 & 9 & 1 & 1 & 5 & 0 & 65 & 60 & 25 & 35 \\
\hline 2005 & 50 & 110 & 10 & 1 & 20 & 0 & 40 & 10 & 20 & 20 \\
\hline 2005 & 51 & 0 & 0 & 0 & 15 & 0 & 10 & 25 & 50 & 40 \\
\hline 2005 & 52 & 0 & 0 & 0 & 20 & 5 & 15 & 20 & 65 & 30 \\
\hline 2005 & 53 & 95 & 5 & 0 & 0 & 5 & 75 & 20 & 25 & 35 \\
\hline 2005 & 54 & 0 & 0 & 0 & 0 & 0 & 75 & 20 & 25 & 35 \\
\hline 2005 & 55 & 0 & 0 & 0 & 15 & 0 & 20 & 24 & 65 & 40 \\
\hline 2005 & 56 & 290 & 30 & 1 & 0 & 15 & 80 & 15 & 20 & 25 \\
\hline 2005 & 57 & 0 & 0 & 0 & 35 & 0 & 15 & 25 & 50 & 60 \\
\hline 2005 & 58 & 0 & 0 & 0 & 10 & 0 & 30 & 40 & 60 & 60 \\
\hline 2005 & 59 & 0 & 0 & 0 & 15 & 0 & 40 & 40 & 45 & 38 \\
\hline 2005 & 60 & 0 & 0 & 0 & 0 & 5 & 75 & 30 & 25 & 40 \\
\hline 2005 & 61 & 0 & 0 & 0 & 0 & 0 & 35 & 45 & 65 & 50 \\
\hline
\end{tabular}

DROS $=$ Drosera stems $/ 0.5 \mathrm{~m}^{2}$ plot $(\mathrm{N})$, and percent cover $/ 0.5 \mathrm{~m}^{2}$ plot ( $\mathrm{C}$ ) $\mathrm{LICH}=$ lichen percent cover in each $0.5 \mathrm{~m}^{2}$ plot $(\mathrm{C})$

UNVG = unvegetated soil percent cover in each $0.5 \mathrm{~m}^{2}$ plot (C)

MOSS $=$ Moss percent cover in each $0.5 \mathrm{~m}^{2}$ plot $(\mathrm{C})$

HERB = Herbaceous vegetation \%cover $(C)$, and mean height $(H)$ for each $0.5 \mathrm{~m}^{2}$ plot

WOOD $=$ Woody vegetation \%cover $(\mathrm{C})$, and mean height $(\mathrm{H})$ for each $0.5 \mathrm{~m}^{2}$ plot 
Appendix C

NESA core raw data for all other plants and variables in 2006

YEAR PLOT DROS_N DROS_C LICH_C UNVG_C MOSS_C HERB_C HERB_H WOOD_C WOOD_H $2006 \quad 1 \quad \begin{array}{lllllllll}198 & 5 & 0 & 10 & 5 & 70 & 30 & 20 & 60\end{array}$

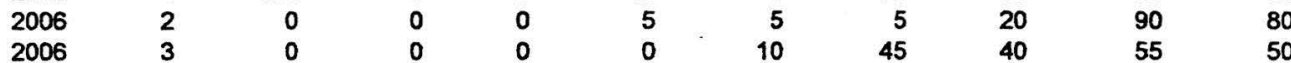
$\begin{array}{llll}5 & 90 & 35 & 10\end{array}$

2006

2006

2006

2006

2006

2006

2006

2006

2006

2006

2006

2006

2006

2006

2006

2006

2006

2006

2006

2006

2006

2006

2006

2006

$2006 \quad 29$

200630

2006

2006

2006

$2006 \quad 34$

2006

2006

2006

200638

$2006 \quad 39$

$2006 \quad 40$

2006

2006

2006

2006

2006

2006

2006

2006

2006

2006

$2006 \quad 51$

$2006 \quad 52$

2006

2006

2006

2006

2006

2006

2006

2006

DROS = Drosera stems $/ 0.5 \mathrm{~m}^{2}$ plot $(\mathrm{N})$, and percent cover $/ 0.5 \mathrm{~m}^{2}$ plot ( C)

$\mathrm{LICH}=$ lichen percent cover in each $0.5 \mathrm{~m}^{2}$ plot $(\mathrm{C})$

UNVG = unvegetated soil percent cover in each $0.5 \mathrm{~m}^{2}$ plot $(C)$

MOSS $=$ Moss percent cover in each $0.5 \mathrm{~m}^{2}$ plot $(\mathrm{C})$

HERB = Herbaceous vegetation \%cover $(\mathrm{C})$, and mean height $(\mathrm{H})$ for each $0.5 \mathrm{~m}^{2}$ plot

WOOD $=$ Woody vegetation \%cover $(C)$, and mean height $(H)$ for each $0.5 \mathrm{~m}^{2}$ plot 
Appendix D

Data for all plots outside of the core for 2005

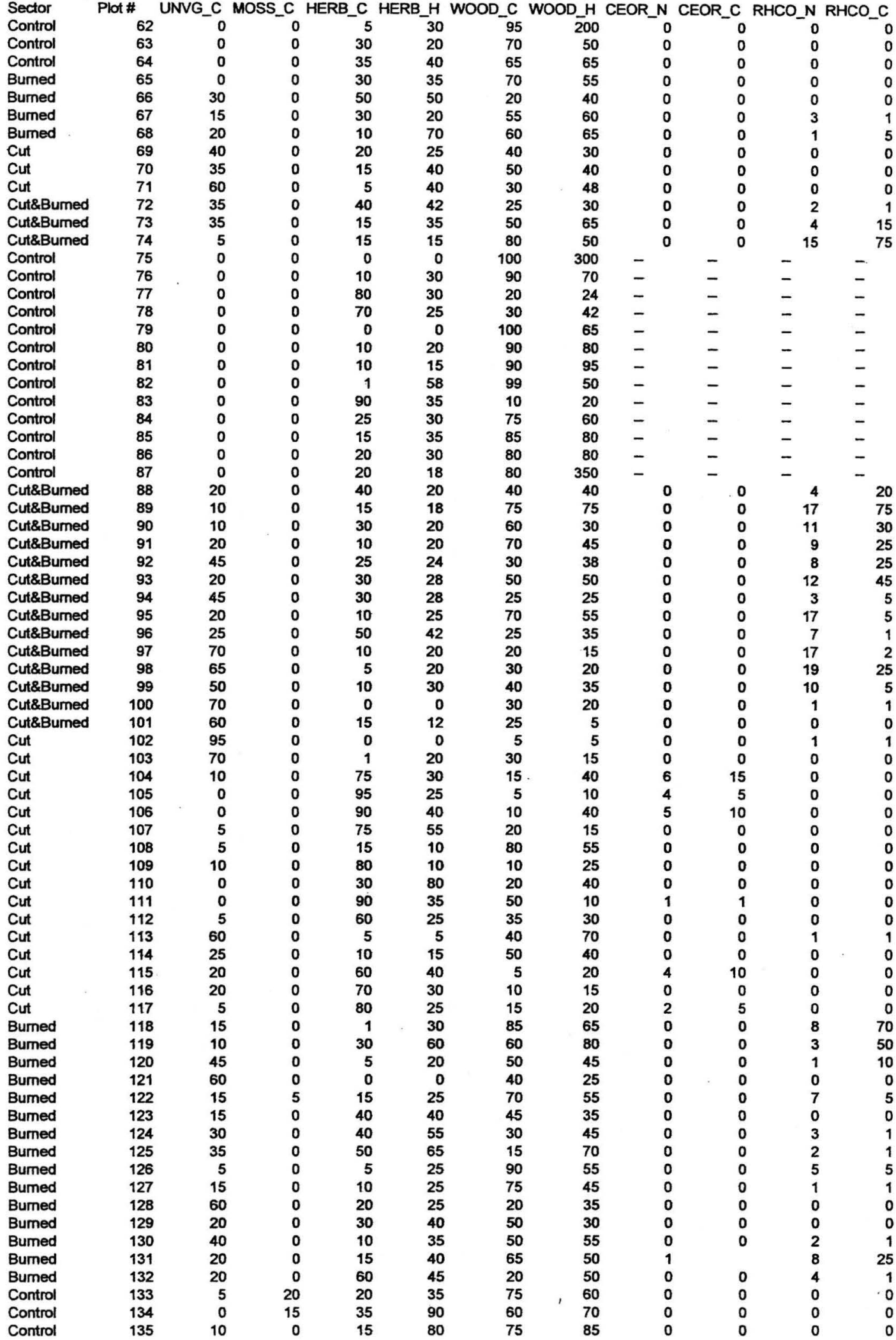




\begin{tabular}{|c|c|c|c|c|c|c|c|c|c|c|c|}
\hline Control & 136 & 80 & 0 & 5 & 20 & 95 & 150 & 0 & 0 & 0 & 0 \\
\hline Control & 137 & 0 & 0 & 20 & 90 & 80 & 120 & 0 & 0 & 0 & 0 \\
\hline Control & 138 & 0 & 0 & 20 & 90 & 90 & 80 & 0 & 0 & 0 & 0 \\
\hline Control & 139 & 0 & 0 & 5 & 15 & 95 & 130 & 0 & 0 & 0 & 0 \\
\hline Control & 140 & 5 & 0 & 20 & 80 & 75 & 100 & 0 & 0 & 0 & 0 \\
\hline Control & 141 & 75 & 0 & 5 & 30 & 90 & 170 & 0 & 0 & 1 & 1 \\
\hline Control & 142 & 1 & 50 & 20 & 15 & 90 & 90 & 0 & 0 & 1 & 1 \\
\hline Control & 143 & 10 & 0 & 60 & 80 & 25 & 70 & 0 & 0 & 0 & 0 \\
\hline Control & 144 & 10 & 0 & 10 & 60 & 90 & 150 & 0 & 0 & 0 & 0 \\
\hline Control & 145 & 30 & 0 & 40 & 50 & 40 & 30 & 0 & 0 & 0 & 0 \\
\hline Control & 146 & 5 & 0 & 15 & 50 & 70 & 90 & 0 & 0 & 1 & 1 \\
\hline Control & 147 & 75 & 0 & 5 & 20 & 20 & 140 & 0 & 0 & 0 & 0 \\
\hline
\end{tabular}

UNVG = unvegetated soil percent cover in each $0.5 \mathrm{~m}^{2}$ plot $(\mathrm{C})$

MOSS = Moss percent cover in each $0.5 \mathrm{~m}^{2}$ plot $(\mathrm{C})$

HERB = Herbaceous vegetation \%cover $(C)$, and mean height $(H)$ for each $0.5 \mathrm{~m}^{2}$ plot

WOOD $=$ Woody vegetation \%cover $(\mathrm{C})$, and mean height $(\mathrm{H})$ for each $0.5 \mathrm{~m}^{2}$ plot

CEOR = Celastrus orbiculatus stems $/ 0.5 \mathrm{~m}^{2}(\mathrm{~N})$ and $\%$ cover $(\mathrm{C})$ for each $0.5 \mathrm{~m}^{2}$ plot

RHCO $=$ Rhus copallina stems $/ 0.5 \mathrm{~m}^{2}(\mathrm{~N})$ and $\%$ cover $\mathrm{C}$ for each $0.5 \mathrm{~m}^{2}$ plot

Appendix D

Data for all plots outside the core in 2006

\begin{tabular}{|c|c|c|c|c|c|c|c|c|c|c|c|}
\hline $\begin{array}{l}\text { Sector } \\
\text { Control }\end{array}$ & Plot \# 62 & UNVG_C & MOSS_C & HERB_C & HERB_H & WOOD_C & WOOD_H & CEOR_N & CEOR_C & $\mathrm{RHCO}_{0} \mathrm{~N}$ & RHCO_C \\
\hline Control & 63 & 0 & 0 & 10 & 70 & 90 & 80 & 0 & 0 & 0 & 0 \\
\hline Control & 64 & 0 & 0 & 30 & 80 & 70 & 90 & 0 & 0 & 0 & 0 \\
\hline Burned & 65 & 0 & 0 & 95 & 50 & 5 & 30 & 0 & 0 & 0 & 0 \\
\hline Bumed & 66 & 0 & 0 & 60 & 50 & 40 & 35 & 1 & 1 & 0 & 0 \\
\hline Bumed & 67 & 0 & 0 & 40 & 35 & 60 & 65 & o & 0 & 3 & 5 \\
\hline Burned & 68 & 5 & 0 & 25 & 70 & 70 & 65 & $\mathbf{0}$ & 0 & 1 & 5 \\
\hline Cut & 69 & 0 & 0 & 60 & 45 & 40 & 65 & 0 & 0 & 0 & 0 \\
\hline Cut & 70 & 0 & 0 & 90 & 35 & 10 & 40 & 3 & 1 & 0 & 0 \\
\hline Cut & 71 & 40 & 0 & 25 & 50 & 35 & 55 & o & 0 & 0 & 0 \\
\hline Cut\&Bumed & 72 & 0 & 0 & 60 & 30 & 40 & 40 & 6 & 5 & 2 & 1 \\
\hline Cut\&Bumed & 73 & 0 & 0 & 55 & 60 & 45 & 55 & 0 & 0 & 3 & 15 \\
\hline Cut\&Burned & 74 & 5 & 0 & 30 & 35 & 65 & 60 & 10 & 10 & 12 & 40 \\
\hline Control & 75 & 0 & 0 & 0 & 0 & 100 & 300 & - & - & - & - \\
\hline Control & 76 & 0 & 0 & 10 & 30 & 90 & 70 & - & - & - & - \\
\hline Control & 77 & 0 & 0 & 80 & 30 & 20 & 24 & - & - & - & - \\
\hline Control & 78 & 0 & 0 & 70 & 25 & 30 & 42 & - & - & - & - \\
\hline Control & 79 & 0 & 0 & 0 & 0 & 100 & 75 & - & - & - & - \\
\hline Control & 80 & 0 & 0 & 10 & 25 & 90 & 80 & - & - & - & - \\
\hline Control & 81 & 0 & 0 & 10 & 15 & 90 & 95 & - & - & - & - \\
\hline Control & 82 & 0 & 0 & 5 & 50 & 95 & 50 & - & - & - & - \\
\hline Control & 83 & 0 & 0 & 85 & 15 & 15 & 20 & - & - & - & - \\
\hline Control & 84 & 0 & 0 & 25 & 35 & 75 & 60 & - & - & - & - \\
\hline Control & 85 & 0 & 0 & 15 & 35 & 85 & 80 & - & - & - & - \\
\hline Control & 86 & 0 & 0 & 20 & 30 & 80 & 80 & - & - & - & - \\
\hline Control & 87 & 0 & 0 & 15 & 25 & 85 & 350 & - & - & - & - \\
\hline Cut\&Bumed & 88 & 50 & 0 & 20 & 30 & 30 & 35 & 0 & 0 & 2 & 5 \\
\hline Cut\&Burned & 89 & 5 & 0 & 50 & 30 & 45 & 65 & 5 & 1 & 13 & 60 \\
\hline Cut\&Bumed & 90 & 5 & 0 & 30 & 15 & 65 & 45 & 0 & 0 & 13 & 30 \\
\hline Cut\&Bumed & 91 & 0 & 0 & 15 & 15 & 85 & 70 & 0 & 0 & 5 & 30 \\
\hline Cut\&Bumed & 92 & 15 & 0 & 50 & 25 & 35 & 35 & 0 & 0 & 9 & 35 \\
\hline Cut\&Bumed & 93 & 5 & 0 & 35 & 30 & 55 & 70 & 2 & 1 & 7 & 25 \\
\hline Cut\&Burned & 94 & 10 & 0 & 75 & 25 & 15 & 40 & 4 & 1 & 7 & 20 \\
\hline Cut\&Burned & 95 & 0 & 0 & 20 & 30 & 80 & 75 & 0 & 0 & 11 & 25 \\
\hline Cut\&Bumed & 96 & 0 & 0 & 35 & 45 & 65 & 35 & 0 & 0 & 7 & 20 \\
\hline Cut\&Bumed & 97 & 15 & 35 & 50 & 30 & 35 & 30 & 0 & 0 & 15 & 30 \\
\hline Cut\&Bumed & 98 & 60 & 10 & 15 & 15 & 25 & 40 & 0 & 0 & 13 & 45 \\
\hline Cut\&Burned & 99 & 15 & 0 & 10 & 35 & 75 & 65 & 0 & 0 & 5 & 30 \\
\hline Cut\&Bumed & 100 & 45 & 0 & 15 & 25 & 40 & 35 & 3 & 1 & 1 & 1 \\
\hline Cut\&Burned & 101 & 30 & 0 & 60 & 15 . & 10 & 15 & 0 & 0 & 0 & 0 \\
\hline Cut & 102 & 85 & 0 & 15 & 25 & 0 & 0 & 0 & 0 & 0 & 0 \\
\hline Cut & 103 & 45 & 20 & 20 & 5 & 30 & 35 & $\uparrow$ & 1 & 0 & 0 \\
\hline Cut & · 104 & 0 & 0 & 85 & 55 & 15 & 40 & 19 & 15 & 0 & 0 \\
\hline Cut & 105 & 0 & 0 & 100 & 35 & 0 & 0 & 15 & 10 & 0 & 0 \\
\hline Cut & 106 & 0 & 0 & 100 & 45 & 0 & 0 & 8 & 10 & 0 & 0 \\
\hline Cut & 107 & 0 & 0 & 100 & 50 & 0 & 0 & 0 & 0 & 0 & 0 \\
\hline Cut & 108 & 0 & 0 & 30 & 15 & 70 & 100 & 3 & 10 & 0 & 0 \\
\hline Cut & 109 & 0 & 0 & 70 & 25 & 30 & 30 & 0 & 0 & 0 & o \\
\hline Cut & 110 & 0 & 0 & 85 & 40 & 15 & 40 & 11 & 5 & 0 & 0 \\
\hline Cut & 111 & 0 & 0 & 85 & 20 & 15 & 30 & 2 & 10 & 0 & 0 \\
\hline Cut & 112 & 15 & 0 & 65 & 35 & 20 & 30 & 5 & 5 & 0 & 0 \\
\hline Cut & 113 & 20 & 0 & 5 & 10 & 75 & 85 & 0 & 0 & 1 & 1 \\
\hline Cut & 114 & 0 & 0 & 30 & 25 & 70 & 55 & 0 & 0 & 0 & 0 \\
\hline Cut & 115 & 15 & 0 & 100 & 55 & 0 & 0 & 9 & 10 & 0 & 0 \\
\hline Cut & 116 & 5 & 0 & 80 & 45 & 15 & 50 & 11 & 10 & 2 & 1 \\
\hline
\end{tabular}




\begin{tabular}{|c|c|c|c|c|c|c|c|c|c|c|c|}
\hline Cut & 117 & 0 & 0 & 80 & 45 & 20 & 40 & 3 & 5 & 0 & 0 \\
\hline Bumed & 118 & 15 & 0 & 1 & 30 & 85 & 65 & 0 & 0 & 6 & 70 \\
\hline Bumed & 119 & 10 & 0 & 35 & 65 & 55 & 80 & 4 & 1 & 3 & 5 \\
\hline Bumed & 120 & 35 & 0 & 5 & 35 & 60 & 45 & 0 & 0 & 1 & 5 \\
\hline Bumed & 121 & 45 & 0 & 10 & 10 & 45 & 30 & 2 & 1 & 0 & 0 \\
\hline Bumed & 122 & 10 & 0 & 20 & 30 & 70 & 60 & 0 & 0 & 5 & 5 \\
\hline Bumed & 123 & 0 & 0 & 95 & 60 & 5 & 20 & 0 & 0 & 0 & 0 \\
\hline Bumed & 124 & 0 & 0 & 90 & 45 & 10 & 60 & 3 & 1 & 1 & 1 \\
\hline Burned & 125 & 0 & 0 & 40 & 65 & 60 & 75 & 0 & 0 & 0 & 0 \\
\hline Burned & 126 & 0 & 0 & 15 & 30 & 85 & 60 & 0 & 0 & 2 & 5 \\
\hline Bumed & 127 & 0 & 0 & 5 & 15 & 95 & 110 & 0 & 0 & 0 & 0 \\
\hline Bumed & 128 & 0 & 0 & 85 & 60 & 15 & 30 & 0 & 0 & 1 & 1 \\
\hline Bumed & 129 & 0 & 0 & 60 & 70 & 40 & 70 & 1 & 1 & 3 & 20 \\
\hline Bumed & 130 & 10 & 0 & 60 & 70 & 30 & 55 & 0 & 0 & 0 & 0 \\
\hline Burned & 131 & 0 & 0 & 55 & 50 & 45 & 80 & 7 & 5 & 5 & 40 \\
\hline Bumed & 132 & 0 & 0 & 80 & 70 & 20 & 60 & 0 & 0 & 3 & 20 \\
\hline Control & 133 & 10 & 15 & 80 & 35 & 20 & 50 & 0 & 0 & 0 & 0 \\
\hline Control & 134 & 0 & 0 & 30 & 70 & 70 & 70 & 0 & 0 & 0 & 0 \\
\hline Control & 135 & 0 & 0 & 35 & 95 & 65 & 65 & 0 & 0 & 0 & 0 \\
\hline Control & 136 & 0 & 0 & 0 & 0 & 100 & 180 & 1 & 1 & 0 & 0 \\
\hline Control & 137 & 0 & 0 & 0 & 0 & 100 & 120 & 0 & 0 & 0 & 0 \\
\hline Control & 138 & 0 & 0 & 5 & 70 & 95 & 85 & 0 & 0 & 0 & 0 \\
\hline Control & 139 & 0 & 0 & 5 & 10 & 95 & 90 & 0 & 0 & 0 & 0 \\
\hline Control & 140 & 0 & 0 & 20 & 70 & 80 & 100 & 0 & 0 & 0 & 0 \\
\hline Control & 141 & 0 & 0 & 5 & 25 & 95 & 120 & 0 & 0 & 1 & 1 \\
\hline Control & 142 & 0 & 15 & 25 & 40 & 75 & 150 & 0 & 0 & 1 & 1 \\
\hline Control & 143 & 0 & 0 & 45 & 50 & 60 & 65 & 0 & 0 & 0 & 0 \\
\hline Control & 144 & 10 & 0 & 30 & 40 & 60 & 100 & 0 & 0 & 0 & 0 \\
\hline Control & 145 & 30 & 0 & 40 & 50 & 40 & 30 & 0 & 0 & 0 & 0 \\
\hline Control & 146 & 5 & 5 & 10 & 50 & 70 & 90 & 0 & 0 & 1 & 10 \\
\hline Control & 147 & 60 & 0 & 20 & 25 & 20 & 150 & 0 & 0 & 0 & 0 \\
\hline
\end{tabular}

UNVG = unvegetated soil percent cover in each $0.5 \mathrm{~m}^{2}$ plot ( C) MOSS $=$ Moss percent cover in each $0.5 \mathrm{~m}^{2}$ plot $(\mathrm{C})$

$\mathrm{HERB}=$ Herbaceous vegetation \%cover $(\mathrm{C})$, and mean height $(\mathrm{H})$ for each $0.5 \mathrm{~m}^{2}$ plot WOOD $=$ Woody vegetation \%cover $(C)$, and mean height $(H)$ for each $0.5 \mathrm{~m}^{2}$ plot CEOR = Celastrus orbiculatus stems/0.5 $\mathrm{m}^{2}(\mathrm{~N})$ and \% cover $(\mathrm{C})$ for each $0.5 \mathrm{~m}^{2}$ plot $\mathrm{RHCO}=$ Rhus copallina stems $/ 0.5 \mathrm{~m}^{2}(\mathrm{~N})$ and $\%$ cover $\mathrm{C}$ for each $0.5 \mathrm{~m}^{2}$ plot 


\section{Bibliography}

Bakker, J.P., E.S. Bakker, E. Rosen, G.L. Verweij, and R.M. Bekker. 1996. Soil seed bank composition along a gradient from dry alvar grassland to Juniperus shrubland. Journal of Vegetation Science 7: 165-176.

Barbaro, L., T. Dutoit, and P. Cozic. 2001. A six-year experimental restoration of biodiversity by shrub-clearing and grazing in calcareous grasslands of the French Prealps. Biodiversity and Conservation 10: 119-135.

Baskin, J.M., K.M. Snyder, J.J. Walck, and C.C. Baskin. 1997. The comparitive autoecology of endemic, globally rare, and geographically-widespread, common plant species: three case studies. The Southwestern Naturalist 42: 384-399.

Brewer, J.S. 1999. Effects of fire, competition and soil disturbances on regeneration of a carnivorous plant (Drosera capillaries). American Midland Naturalist 141: $28-42$.

Briggs, J.M, A.K. Knapp, and B.L. Brock. 2002. Expansion of woody plants in tallgrass prarie: a fifteen-year study of fire and fire-grazing interactions. American Midland Naturalist 147: 287-294.

Brumback, W.E. and L.J. Mehrhoff. 1996. Flora Conservanda: New England. The New England Plant Conservation Program (NEPCoP) list of plants in need of conservation. Rhodora 98: 235-361.

Bullock, J.M. and R.J. Pakeman. 1997. Grazing of lowland heath in England: Management methods and their effects on heathland vegetation. Biological Conservation 79: 1-13.

Carter, R.E., M.D. MacKenzie, D.H. Gjerstad, and D. Jones. 2004. Species composition of fire disturbed ecological land units in the southern loam hills of south Alabama. Southeastern Naturalist 3: 297-308.

Clarke, G.L. and W.A.Patterson. 2006. The distribution of disturbance dependant rare plants on a Massachusetts sandplain: Implications for conservation and management. Biological Conservation 136: 4-16.

Dobson, A., J. Rodriguez, W. Roberts, and D. Wilcove. 1997. Geographic distribution of endangered species in the United States. Science 275: 550-553.

Dolman, P.M. and W.J. Sutherland. (1992) The ecological changes of Breckland grass heaths and the consequences of management. Journal of Applied Ecology 29: 402-413. 
Eldridge, D.J., W.S. Semple, and T.B. Koen. 2000. Dynamics of Cryptogamic soil crusts in a derived grassland in South Eastern Australia. Austral Ecology 25: 232-240.

Ellsworth, J.W., R.A. Harrington, and J.H. Fownes. 2004. Seedling emergence, growth, and allocation of Oriental bittersweet: effects of seed input, seed bank, and forest floor litter. Forest Ecology and Management 190: 255-264.

Enser, R.W. 2002. Rare Native Plants of Rhode Island. Rhode Island Natural Heritage Program, Rhode Island Department of Environmental Management, Providence Rhode Island, USA.

Farnsworth, E.J. and D.E. Ogurcak. 2006. Biogeography and decline of rare plants in New England: historical evidence and contemporary monitoring. Ecological Applications 16: 1327-1337.

Foster, D.R. 2002. Thoreau's country: a historical-ecological perspective on conservation in the New England landscape. Journal of Biogeography 29: 1537-1555.

Foster, D.R. and G. Motzkin. 2003. Interpreting and conserving the openland habitats of coastal New England: insights from landscape history. Forest Ecology and Management 185: 127-150.

Gankin, R. and J. Major. 1964. Arctostaphylos myrtifolia, its biology and relationship to the problem of endemism. Ecology 45: 792-808.

Givinsh, T.J., E.L. Burkhardt, R.E. Happel and J.D. Weintraub. 1984. Carnivory in the bromeliad Brocchinia reducta, with a cost/benefit model for the general restriction of carnivorous plants to sunny, moist, nutrient-poor habitats. American Naturalist 124: 479-497.

Glasgow, L.S. and G.R. Matlack. 2007. Prescribed burning and understory composition in a temperate deciduous forest, Ohio, USA. Forest Ecology and Management 238: $54-64$.

Greenberg, C.H., L.M. Smith and D.J. Levey. 2001. Fruit fate, seed germination and growth of an invasive vine - an experimental test of 'sit and wait' strategy. Biological Invasions 3: 363-372.

Gordon, D.R. 1996. Experimental translocation of the endangered shrub Apalachicola rosemary Conradina glabra to the Apalachicola Bluffs and Ravines Preserve, Florida. Biological Conservation 77: 19-26. 
Hall, B., G. Motzkin, D.R. Foster, M. Syfert, and J. Burk. 2002. Three hundred years of forest and land-use change in Massachusetts, USA. Journal of Biogeography 29: 1319-1335.

Hartnett, D.C. 1987. Effects of fire on clonal growth and dynamics of Pityopsis graminifolia (Asteraceae). American Journal of Botany 74: 1737-1743.

Hassl, A. and S. Spackman. 1995. Effects of fire on threatened and endangered plants: an annotated bibliography. U.S. Department of the Interior, Washington, D.C.

Heisler, J.L., J.M. Briggs, and A.K. Knapp. 2003. Long-term patterns of shrub expansion in $\mathrm{a} \mathrm{C}_{4}$-dominated grassland: fire frequency and the dynamics of shrub cover and abundance. American Journal of Botany 90: 423-428.

Jacobson, G.L., H. Almquist-Jacobson, and J.C. Winne. 1991. Conservation of rare plant habitat: insights from the recent history of vegetation and fire at Crystal Fen, northern Maine, USA. Biological Conservation 57: 287-314.

Juniper, B.E., R.J. Robbins, and D.M. Joel. 1989. The Carnivorous Plants. Academic Press, London, United Kingdom.

Keller, P. and K. Killingbeck. 2004. Responses of rare plants to shrub-cutting and fire at the Ninigret Endangered Species Area, Final Report. U.S. Fish and Wildlife Service, RI National Wildlife Refuge Complex.

Killingbeck, K.T., B. Deegan, and R. Flores. 1998. Rare plant abundance in an endangered species "hot spot." Northeastern Naturalist 5: 283-292.

Kirkpatrick, J. B. and L. Gilfedder. 1995. Maintaining integrity compared with maintaining rare and threatened taxa in remnant bushland in subhumid Tasmania. Biological Conservation 74: 1-8.

Latham, R.E. 2003. Shrubland longevity and rare plant species in the northeastern United States. Forest Ecology and Management 185: 21-39.

Lamont, B. B. and H. V. Runciman. 1993. Fire may stimulate flowering, branching, seed production and seedling establishment in two kangaroo paws (Haemodoraceae). Journal of Applied Ecology 30: 256-264.

Lunt, I. D. 1997. Effects of long-term vegetation management on remnant grassy forests and anthropogenic native grasslands in South-Eastern Australia. Biological Conservation 81: 287-297.

Marks, P.L. 1983. On the origin of the field plants of the northeastern United States. The American Naturalist 122: 210-228. 
McNab, W.H. and D.L. Loftis. 2002. Probability of occurrence and habitat features for oriental bittersweet in an oak forest in the southern Appalachian mountains, USA. Forest Ecology and Management 155: 45-54.

Menges, E.S. 1986. Predicting the future of rare plant populations: demographic monitoring and modeling. Natural Areas Journal 6: 13-25.

Motzkin, G. and D.R. Foster. 2002. Grasslands, Heathlands and Shrublands in coastal New England: historical interpretations and approaches to conservation. Journal of Biogeography 29: 1569-1590.

Muller, S. 2002. Diversity of management practices required to ensure conservation of rare and locally threatened plant species in grasslands: a case study at a regional scale (Lorraine, France). Biodiversity and Conservation 11: 11731184.

Neill, C., B. Von Holle, K. Kleese, K. D. Ivy, A. R. Collins, C. Treat, and M. Dean. 2007. Historical influences on the vegetation and soils of the Martha's Vineyard, Massachusetts coastal sandplain: implications for conservation and restoration. Biological Conservation 136: 17-32.

Norton, D. A., P. J. De Lange. 2003. Fire and vegetation in a temperate peat bog: implications for the management of threatened species. Conservation Biology 17: 138-148.

Platt, W.J, G.W. Evans, M.M. Davis. 1988. Effects of fire season on flowering of forbs and shrubs in longleaf pine forests. Oecologia 76: 353-363.

RIGIS. 1989. Rhode Island State Boundary Datalayer. Rhode Island Geographic Information System. www.edc.uri.edu/rigis/April, 2007.

RIGIS. 2005. RIDOT Digital Orthophotos (2003-2004). Rhode Island Geographic Information System. www.edc.uri.edu/rigis/ April, 2007.

Rutters, C., B. McKenzie, and L.M.Raitt. 1993. Life-history studies of the perennial geophyte Haemanthus pubescens L. subspecies pubescens (Amaryllidaceae) in lowland coastal fynbos, South Africa. International Journal of Plant Science 154: 441-449.

Schemske, D.W., B.C. Husband, M.H. Ruckelshaus, C.Goodwillie, I.M. Parker, and J.G. Bishop. 1994. Evaluating approaches to the conservation of rare and endangered plants. Ecology 75: 584-606. 
Sedia, E. G., and J.G. Ehrenfeld. 2003. Lichens and mosses promote alternate stable plant communities in the New Jersey Pinelands. Oikos 100: 447-458.

Sharp, P. 2004. Platanthera ciliaris (L.) Lindl. Yellow-fringed orchis - Conservation and Research Plan for New England. New England Wildflower Society, Framingham Massachusetts, USA.

Silveri, A., P.W. Dunwiddie and H.J. Michaels. 2001. Logging and edaphic factors in the invasion of an Asian woody vine in a mesic North American forest. Biological Invasions 3: 379-389.

Silvertown, J., D. A. Wells, M. Gillman, M. E. Dodd, H. Roberston, and K. H. Lakhani. 1994. Short-term effects and long-term after-effects of fertilizer application on the flowering population of green-winged orchid Orchis morio. Biological Conservation 69: 191-197.

Stuckey, I. H. 1967. Environmental factors and the growth of native orchids. American Journal of Botany 54: 232-241.

Sullivan, V.I. 1973. Biosystematics of Aletris lutea Small, Aletris obovata Nash, and natural hybrids (Liliaceae). Brittonia 25: 294-303.

Van Lear, D.H., W.D. Carroll, P.R. Kapeluck, and R.Johnson. 2005. History and restoration of the longleaf pine-grassland ecosystem: implications for species at risk. Forest Ecology and Management 211: 150-165.

Verboom, G. A., W. D. Stock, and H. P. Linder. 2002. Determinants of post fire flowering in the geophytic grass Ehrharta capensis. Functional Ecology 16: 705-713.

Vickery, P. D. 2002. Effects of the size of prescribed fire on insect predation Northern Blazing Star, a rare grassland perennial. Biological Conservation 16: 413-421.

Whelan, R. J. 1995. The ecology of fire. Cambridge University Press, Cambridge, United Kingdom.

Wilkinson, L. 1992. SYSTAT for Macintosh, Version 5.2. SYSTAT, Evanston, Illinois.

Wotavova, K., Z. Balounova, and P. Kindlmann. 2004. Factors affecting persistence of terrestrial orchids in wet meadows and implications for their conservation in a changing agricultural landscape. Biological Conservation 118: 271-279.

Zaremba, R.E. 2004. Scleria pauciflora Muhlenberg ex Willdenow var. caroliniana Alph. Wood and Scleria pauciflora Muhlenberg ex Willdenow var. 
pauciflora. (Few-flowered nut-rush) Conservation and Research Plan for New England. New England Wild Flower Society, Framingham Massachusetts, USA.

Zobel, M., S.Suurkask, E. Rosen, and M. Partel. 1996. The dynamics of species richness in an experimentally restored calcareous grassland. Journal of Vegetation Science 7: 203-210. 